\title{
Idaho National Laboratory Cultural Resource Management Office FY 2010 Activity Report
}

Hollie K. Gilbert

Clayton F. Marler

Christina L. Olson

Brenda R. Pace

Julie Braun Williams

September 2011
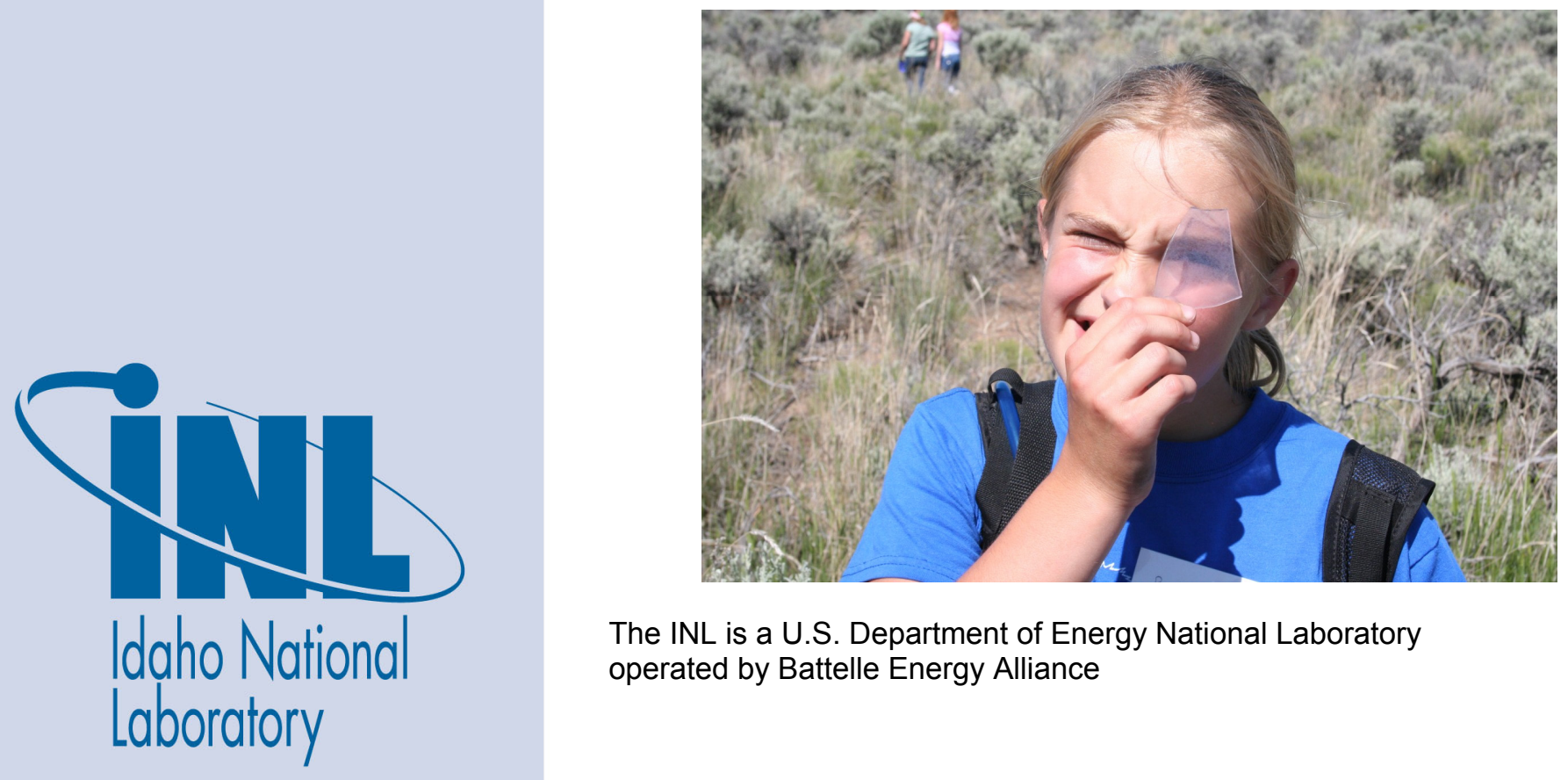

The INL is a U.S. Department of Energy National Laboratory operated by Battelle Energy Alliance 


\section{DISCLAIMER}

This information was prepared as an account of work sponsored by an agency of the U.S. Government. Neither the U.S. Government nor any agency thereof, nor any of their employees, makes any warranty, expressed or implied, or assumes any legal liability or responsibility for the accuracy, completeness, or usefulness, of any information, apparatus, product, or process disclosed, or represents that its use would not infringe privately owned rights. References herein to any specific commercial product, process, or service by trade name, trade mark, manufacturer, or otherwise, does not necessarily constitute or imply its endorsement, recommendation, or favoring by the U.S. Government or any agency thereof. The views and opinions of authors expressed herein do not necessarily state or reflect those of the U.S. Government or any agency thereof. 


\title{
Idaho National Laboratory Cultural Resource Management Office FY 2010
}

\author{
Hollie K. Gilbert \\ Clayton F. Marler \\ Christina L. Olson \\ Brenda R. Pace \\ Julie Braun Williams
}

September 2011

Idaho National Laboratory Idaho Falls, Idaho 83415

http://www.inl.gov

\author{
Prepared for the \\ U.S. Department of Energy \\ Office of Nuclear Energy \\ Under DOE Idaho Operations Office \\ Contract DE-AC07-05ID14517
}






\begin{abstract}
The Idaho National Laboratory (INL) Site is home to vast numbers and a wide variety of important cultural resources representing at least a 13,500-year span of human land use in the region. As a federal agency, the Department of Energy, Idaho Operations Office (DOE-ID) has legal responsibility for the management and protection of the resources and has contracted these responsibilities to Battelle Energy Alliance (BEA). The BEA professional staff is committed to maintaining a cultural resource management program that accepts the challenge of preserving INL cultural resources in a manner reflecting their importance in local, regional, and national history.

This report summarizes activities performed by the INL Cultural Resource Management Office (CRMO) staff during fiscal year 2010. This work is diverse, far-reaching and though generally confined to INL cultural resource compliance, also includes a myriad of professional and voluntary community activities. This document is intended to be informative to both internal and external stakeholders and to serve as a planning tool for future INL cultural resource management work.
\end{abstract}




\section{CONTENTS}

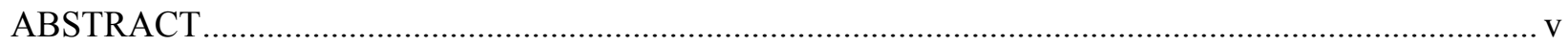

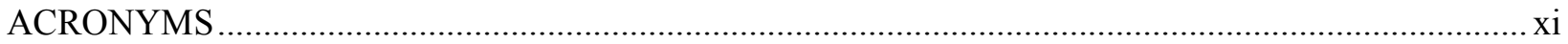

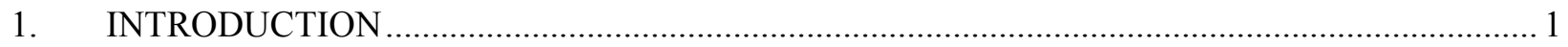

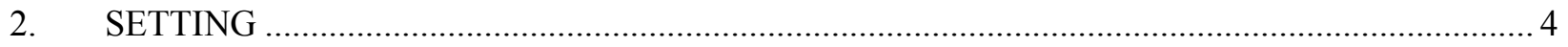

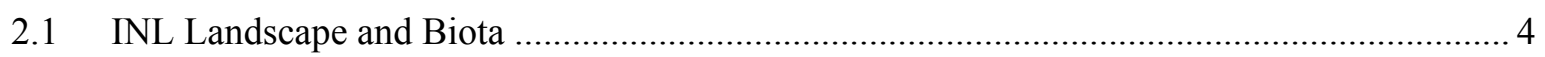

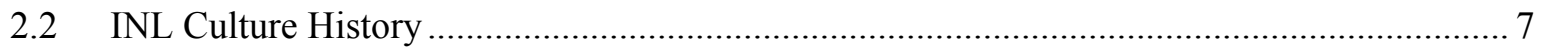

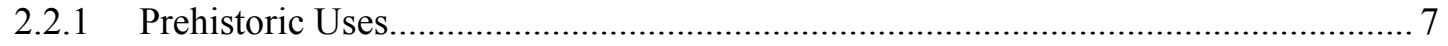

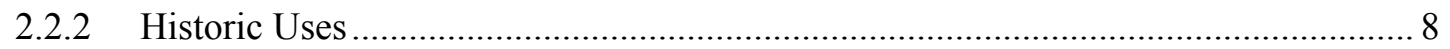

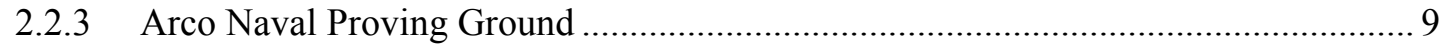

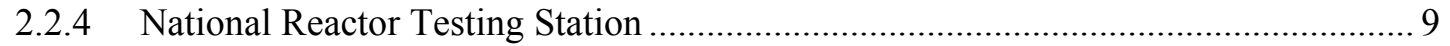

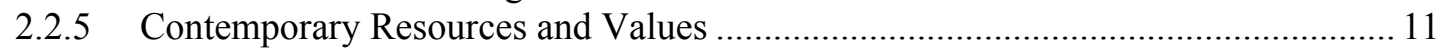

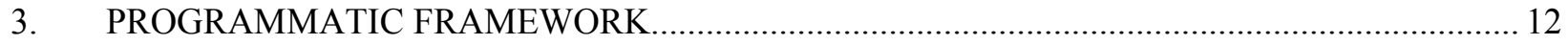

4. INL CULTURAL RESOURCE PROGRAM PERSONNEL ..................................................... 13

5. CULTURAL RESOURCE MANAGEMENT OFFICE ACTIVITIES ....................................... 17

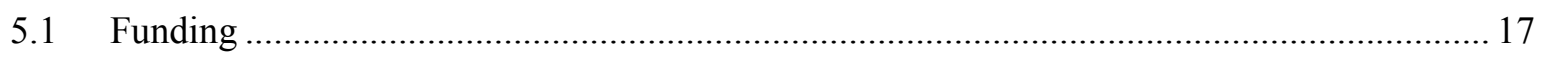

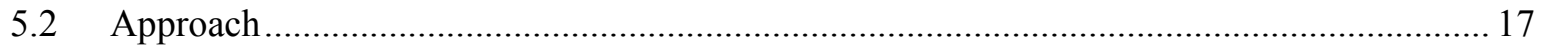

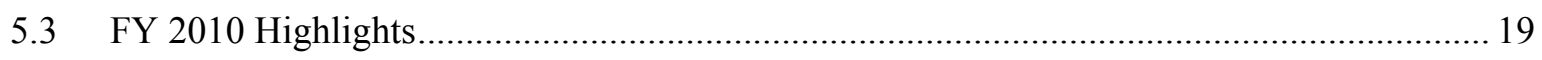

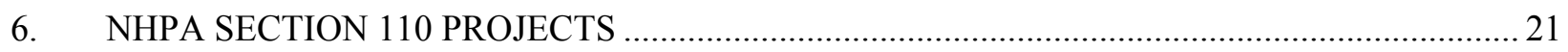

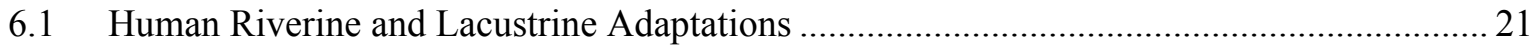

6.2 INL Archive Center and CRM Project Files .................................................................... 22

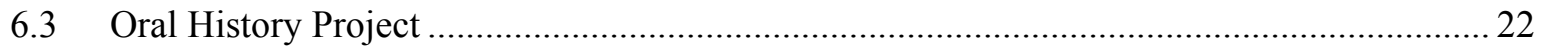

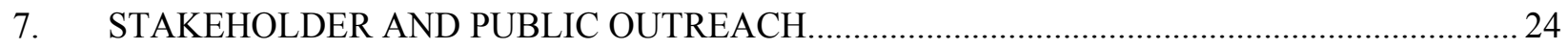

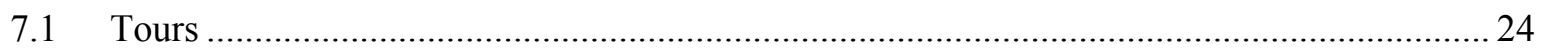

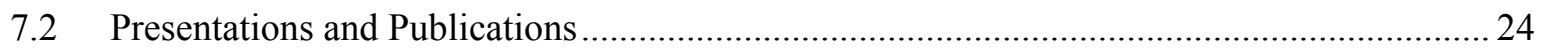

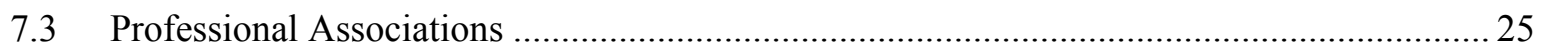

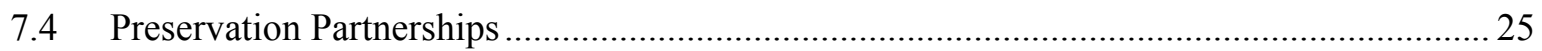

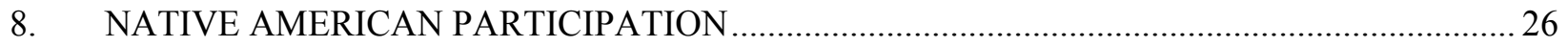

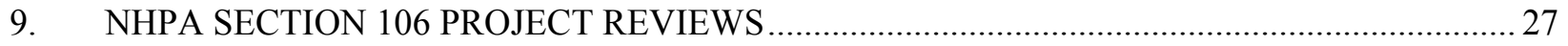

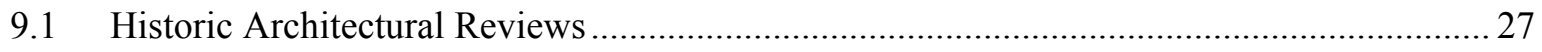

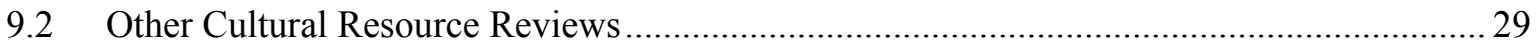

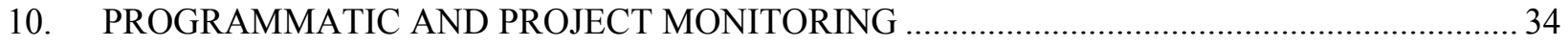

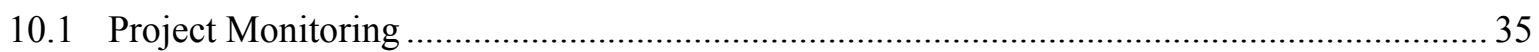

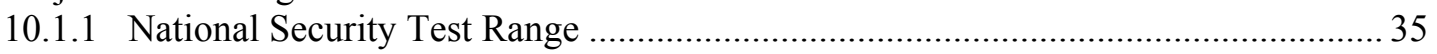

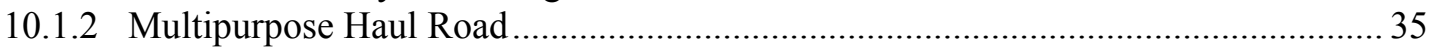

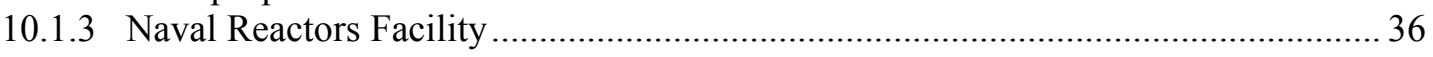




\section{FIGURES}

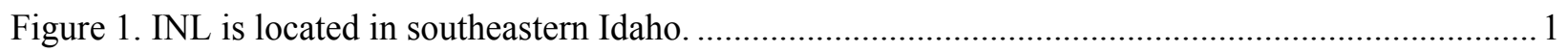

Figure 2 . There are currently nine main facility areas at INL......................................................... 2

Figure 3. View of East Butte from the top of Middle Butte. .............................................................. 4

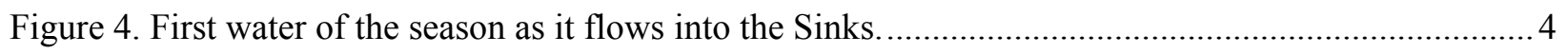

Figure 5. Concrete diversion on the dry Big Lost River, built ca 1910 ................................................. 5

Figure 6. Aerial view of 2010 Jefferson fire in relationship to the CITRC area..................................... 6

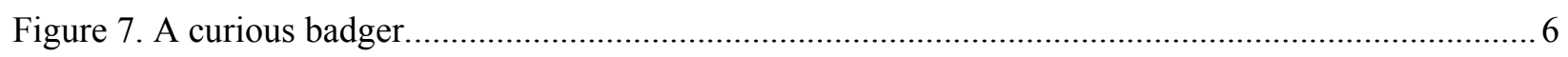

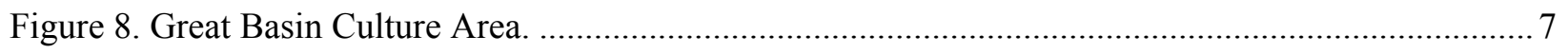

Figure 9. A potential Clovis preform found during a Section 106 project near NRF............................... 7

Figure 10. Impassable historic stage road (T-5) after a Spring thunderstorm........................................ 8

Figure 11. 1943 gantry crane used to offload guns used by the Pacific Naval Fleet. ................................ 9

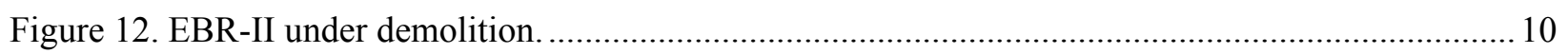

Figure 13. Middle Butte Cave is a place that is both historically and prehistorically important. .............. 11

Figure 14. Teresa Perkins and Robert Gallegos, DOE-ID (Bob Pence not shown)................................. 13

Figure 15. Caroline Boyer Smith, Willie Preacher, and LaRae Buckskin, Shoshone-Bannock

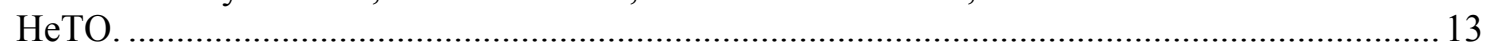

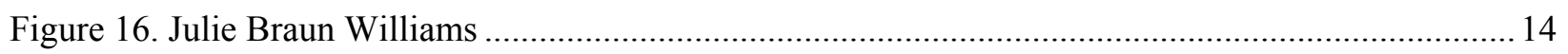

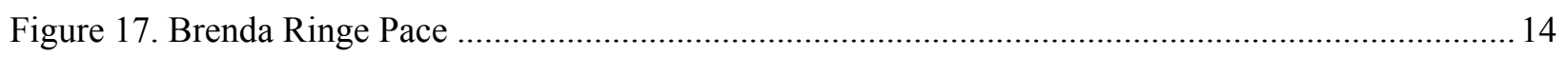

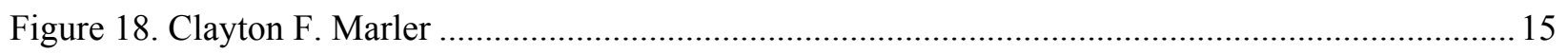

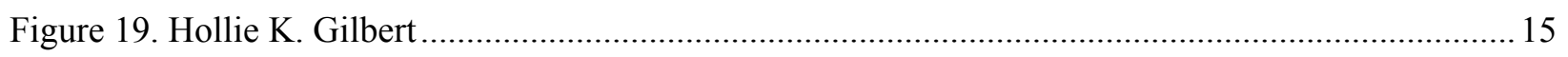

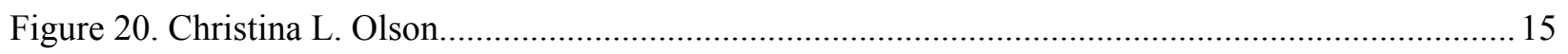

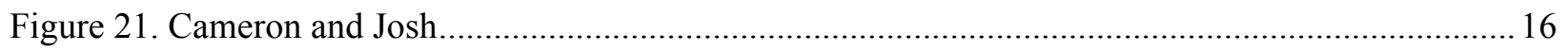

Figure 22. Internal INL professional exchange presentation........................................................ 19

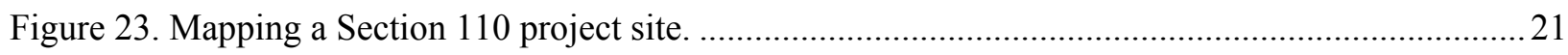

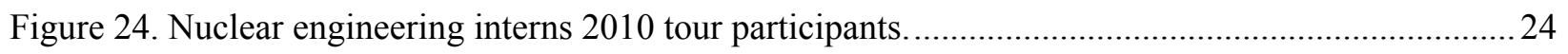

Figure 25. Tribal and INL archaeologists conducting project test excavation.......................................26

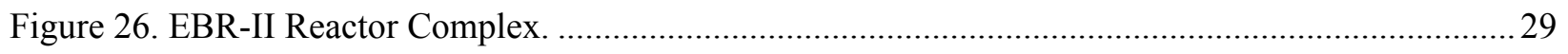

Figure 27. Archaeological sites were marked for avoidance in some FY 2010 project areas. ................... 33 
Figure 28. INL CRM and HeTO tribal representatives at 10-JF-88 (Hellofasite).

\section{TABLES}

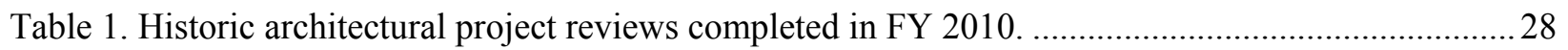

Table 2. Non-architectural project reviews completed in FY 2010 ....................................................... 29 


\section{ACRONYMS}

ACHP Advisory Council on Historic Preservation

AEC U.S. Atomic Energy Commission

AIP Agreement in Principle

ANPG Arco Naval Proving Ground

ARPA Archaeological Resource Protection Act

BBWI Bechtel Babcock \& Wilcox Idaho

BLM Bureau of Land Management

BEA Battelle Energy Alliance

CFA Central Facilities Area

CDRL Contract Data Requirements List

CITRC Critical Infrastructure Test Range Complex

CRM Cultural Resource Management

CRMP Cultural Resource Management Plan

CRMO Cultural Resource Management Office

CWI CH2M Hill/Washington Group International

DD\&D decontamination, deactivation, and demolition

DMS data management system

DOE-ID U.S. Department of Energy - Idaho Operations Office

DOI Department of Interior

EBR I Experimental Breeder Reactor I

$\mathrm{ft} \quad$ foot

FTE full-time equivalent

FY fiscal year

GIS geographical information system

HAER Historic American Engineering Record

HeTO Heritage Tribal Office (Shoshone-Bannock)

ICP Idaho Completion Project

in inch

INEL Idaho National Engineering Laboratory

INEEL Idaho National Engineering and Environmental Laboratory

INL Idaho National Laboratory

INTEC Idaho Nuclear Technology and Engineering Center

ISMS Integrated Safety Management System 
ITD Idaho Transportation Department

MFC Materials and Fuels Complex

NARA National Archives and Records Administration

NEPA National Environmental Policy Act

NHPA National Historic Preservation Act

NRF Naval Reactors Facility

NRHP National Register of Historic Places

NRTS National Reactor Testing Station

PA Programmatic Agreement

PBF Power Burst Facility

RTC Reactor Technology Complex

RWMC Radioactive Waste Management Complex

SHPO State Historic Preservation Office

TRA Test Reactor Area

USC United States Code

WWII World War II 


\section{Idaho National Laboratory Cultural Resource Management Office FY 2010 \\ 1. INTRODUCTION}

The Idaho National Laboratory (INL) is the nation's premier nuclear research laboratory, a multi-program facility, and a National Environmental Research Park located in southeast Idaho under the jurisdiction of the Department of Energy, Idaho Operations Office (DOE-ID) and some joint responsibility with the Bureau of Land Management in established grazing allotments. The INL consists of an 890 square mile reserve located approximately 25 miles west of Idaho Falls and approximately 12 miles east of Arco, along with a number of administrative buildings and laboratories located in Idaho Falls. Management and operations at the INL Site are under the direction of Battelle Energy Alliance (BEA), while they and other agencies, such as the Department of Homeland Security, contractors and subcontractors such as CH2M Hill/Washington Group International (CWI) and Bechtel BWXT Idaho (BBWI) implement specific work scopes.

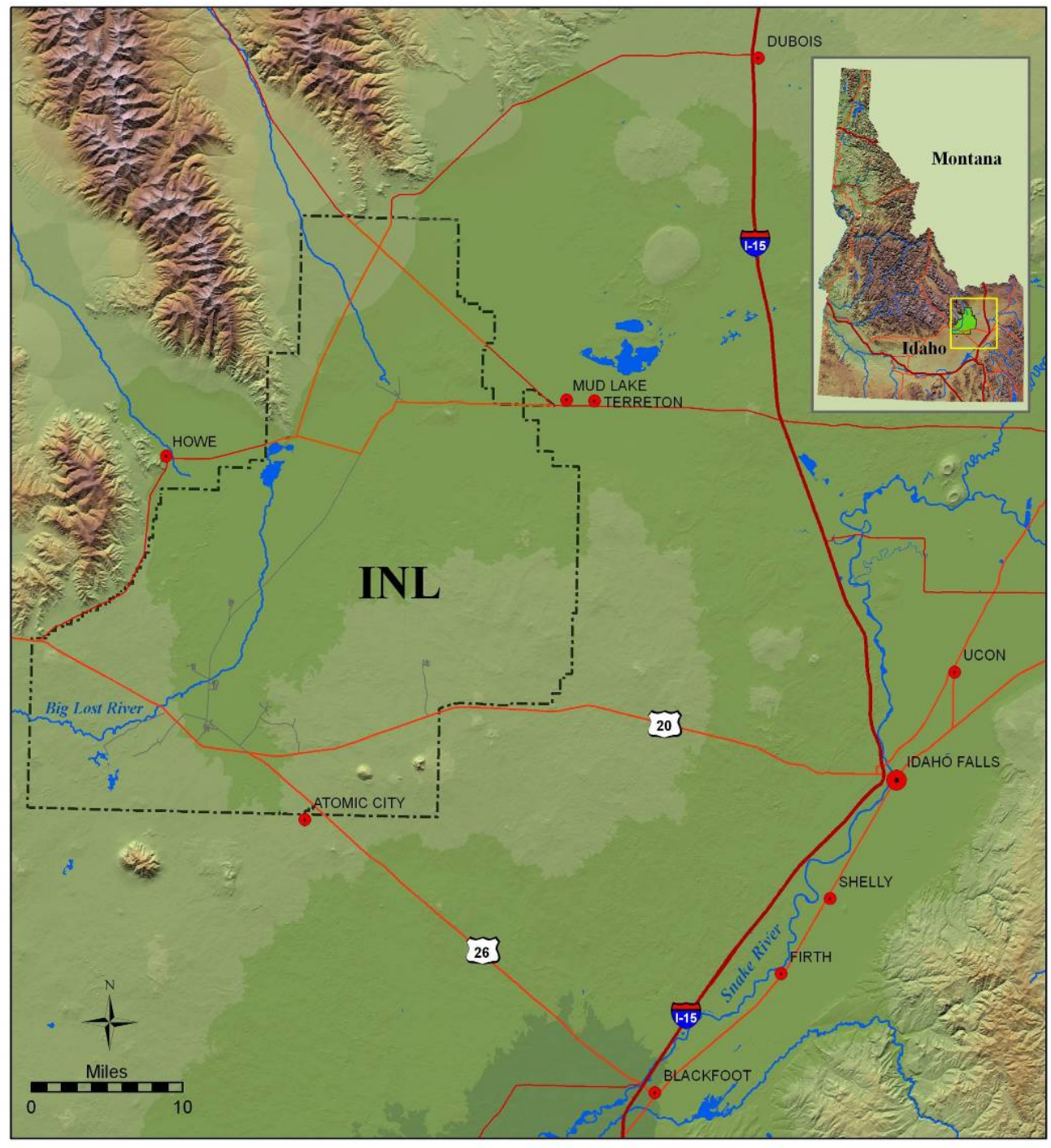

Figure 1. INL is located in southeastern Idaho. 
DOE-ID and its contractors occupy eight main facility areas at the INL Site and several buildings in Idaho Falls. Nearly 300 DOE-ID owned historic buildings and several hundred other property types (e.g., roads, manmade ponds, concrete abutments) have been identified within the eight facility areas. Bechtel Bettis operates a ninth INL facility, the Naval Reactors Facility (NRF), under the supervision of the DOE Office of Naval Reactors. The land between the facility areas is largely undeveloped and dotted with prehistoric and historic cultural resources dating back at least 13,500 years and natural and manmade features that are important to Native Americans and others.

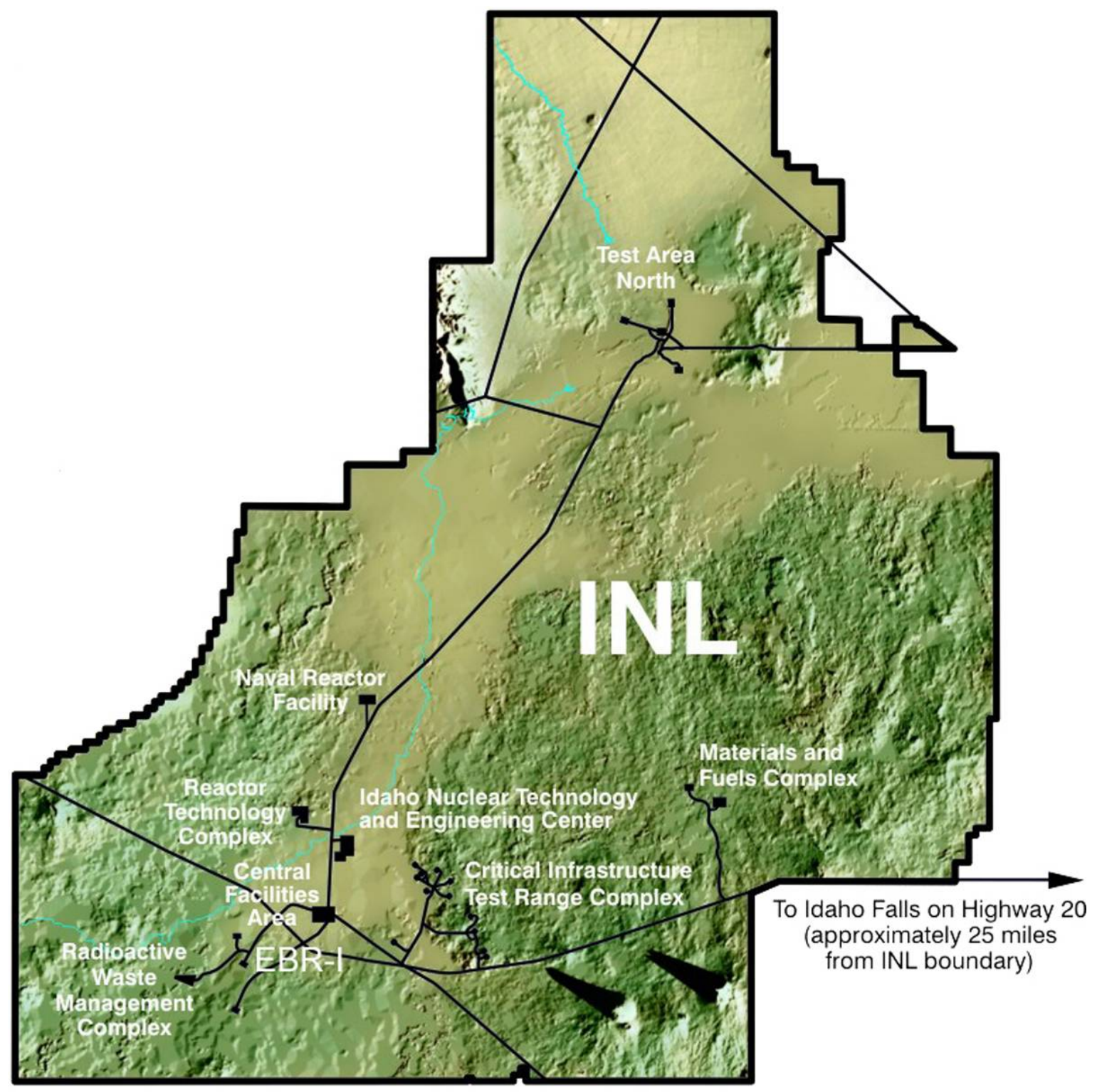

Figure 2 . There are currently nine main facility areas at INL.

Cultural resource management (CRM) at the INL is conducted and coordinated by BEA's professional staff with general oversight provided by DOE-ID. As the centralized repository for cultural resource files, historic INL archives and multi-disciplinary expertise, the INL Cultural Resource Management Office (CRMO) also assists other Site contractors with historic data searches, project reviews, cultural surveys, and regulatory compliance. INL CRMO work balances the nuclear mission and 
new and existing projects with the need to remove or stabilize the remnants of past activities and the need to protect irreplaceable cultural resources.

This summary of activities satisfies an important requirement of the "INL Cultural Resource Management Plan" (CRMP) (DOE-ID 2011) and the associated programmatic agreement between the DOE-ID, Idaho State Historic Preservation Office (SHPO), and Advisory Council on Historic Preservation (ACHP). The summary is intended for a diverse audience and to encourage awareness of and appreciation for INL cultural resources. Photographs taken by INL CRMO staff provide a visual context for many of the activities discussed in the text. Ultimately, the document is intended to stimulate discussion resulting in the promotion and advancement of INL CRM program goals. 


\section{SETTING}

\subsection{INL Landscape and Biota}

The INL is an 890 square mile reserve located within the Great Basin Culture Area on the northern margins of the Eastern Snake River Plain (Nace et al. 1972), tucked against the foothills of the Beaverhead, Lemhi, and Lost River Ranges. Locally prominent landmarks such as Big Southern, Middle, East, Antelope, and Circular Buttes are volcanic in origin and tend to dominate a landscape that otherwise appears deceptively flat. In reality, the lava terrain features ridges and swales, playas, craters, buttes, and caves. The Big Lost River has created a broad and relatively flat floodplain that is bordered by the rugged basaltic terrain. Extensive gravel deposits and a multitude of channels characterize the floodplain and reflect a more active period in the River's history.

The broad trough of the Big Lost River is also known as the Pioneer Basin (Butler 1968). It is a closed topographic depression, fed by drainage systems that extend between Big Southern, Middle, and

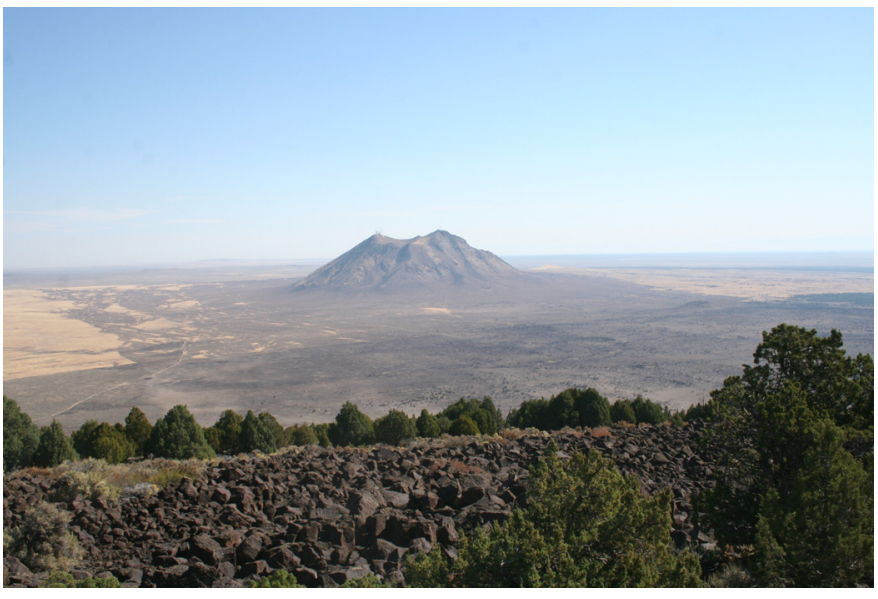

Figure 3. View of East Butte from the top of Middle Butte. East Buttes to the south, and Mud Lake, the Big and Little Lost Rivers, and Birch Creek to the north. The central feature of the Basin is the Big Lost River itself, which enters the INL Site from the west, flowing in an easterly direction for about six miles before turning northward. Along the way the River winds through a broad alluvial plain interspersed with basalt outcrops and cut by numerous channels for some 25 miles before a combination of stream flow rates, gradient, and soil porosity cause it to disappear or sink into the Snake River Plain Aquifer in a low area at the base of the Lemhi Mountains. The Little Lost River and Birch Creek also terminate in natural "Sink" areas at the northeastern end of the Pioneer Basin.

The Big Lost River has endured significant natural and artificial modifications during its long history and natural channels that may have held water during times of greater effective moisture remain dry today due to cyclic drought combined with large-scale irrigation projects initiated in the early $20^{\text {th }}$ century. The "Sinks" have also been affected by climate change and historic irrigation practices. Today they are seasonal wetlands that remain dry most years, but in the past during cooler and wetter conditions, they were part of a major inland lake known as Lake Terreton.

Lake Terreton was a shallow freshwater lake that dominated the northern reaches of the Pioneer Basin throughout much of the Pleistocene. Spreading over hundreds of square kilometers, it likely reached its maximum highstand at the end of the last ice age about 13,000 years ago with the

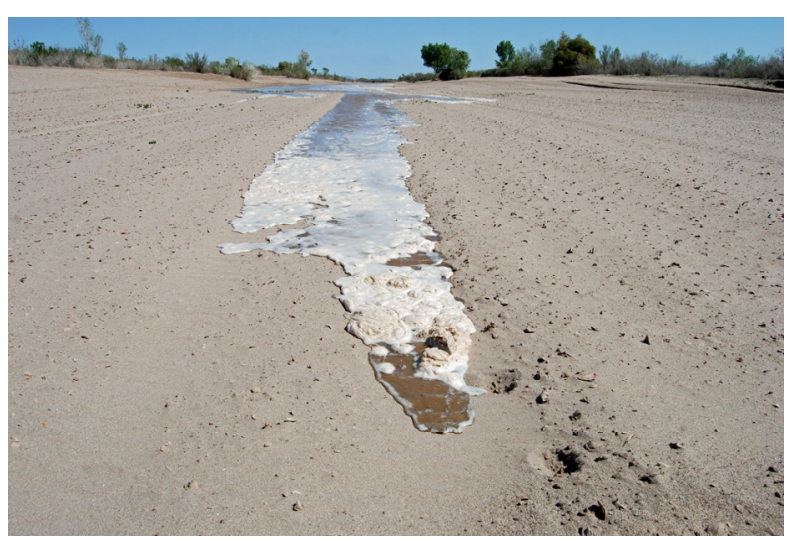

Figure 4. First water of the season as it flows into the Sinks. 
addition of meltwater from retreating montane glaciers (Butler 1970, Gianniny et al. 2002, Ostenaa 1999). On lands now within the boundaries of INL, greater effective moisture and reliable flows from Birch Creek and the Big and Little Lost Rivers fed a western sub-basin of the Lake approximately 90 square miles in extent. Farther to the east, Camas and Beaver Creeks sustained an eastern sub-basin known today as Mud Lake, located roughly 20 miles northeast of the INL. The cooler and wetter conditions that sustained Lake Terreton during the Pleistocene geological period also favored local rivers and numerous smaller playas that dot the landscape. Plants like grasses and rushes flourished under these conditions. Warming and drying trends since the end of the Pleistocene have resulted in changes in the relative percentages of each plant species but virtually all species that existed then still exist today (Davis and Bright 1983).

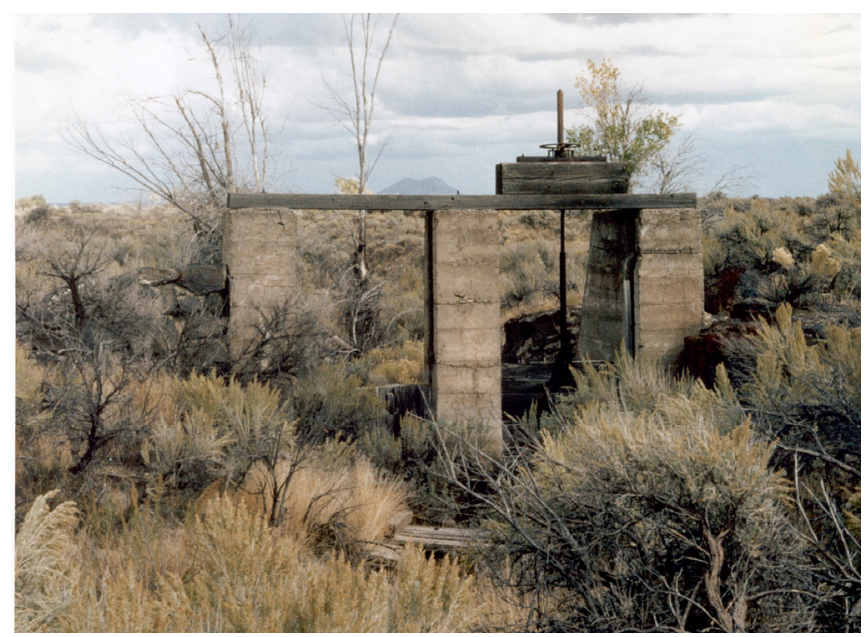

Figure 5. Concrete diversion on the dry Big Lost River, built ca 1910 .

Throughout history, water has been central in land-use choices. This is especially true on the arid INL lands. Surface features like the streams, rivers, and large seasonal wetlands created at the "Sinks" have attracted animals and human hunter-gatherers, farmers, and ranchers with the lure of moisture in the cold desert environment. During cooler and moister climatic intervals from 22,000 12,000 years ago and possibly as recently as 720 years ago, hunter-gatherers were drawn to the resources offered by Lake Terreton. As conditions have dried in historic times, Lake Terreton has been reduced to a series of discontiguous semi-seasonal marshland playas and local rivers flow only on a seasonal basis. Water diversions of many kinds, including simple hand-dug ditches and carefully

engineered canals were created across the INL desert during historic times to deliver the precious water to hopeful settlers on homestead claims systematically established throughout the Pioneer Basin from the late 1800 s through approximately 1925 . During this period of settlement, surface water became increasingly scarce and recurrent cycles of drought, soil porosity, and upstream irrigation, strongly affected these local habitations, leading to abandonment by most. INL CRMO research is filling in many of the details of the lives of the hunter-gatherers and pioneers who lived on these arid lands, and the inevitable cycles of boom and bust linked intimately to water in the high desert. In modern times, the extensive aquifer that underlies the region has become accessible through enhanced technology and new needs based in scientific endeavor. 
Modern biotic communities on the INL are similar to those found in other cool desert environments within the Great Basin Culture Area. Plant species vary according to altitude from shadscale steppe to sagebrush and grass dominated communities to higher altitudes dominated by juniper along the slopes of the larger buttes and the mountain foothills. Various native grasses, low shrubs, and forbs are present in virtually all plant communities (Anderson et al 1996). In addition to large scale climatic changes, human activity, most notably within historic times, has affected INL vegetation. Agricultural attempts have left visible field scars and have introduced nonnative crop species. Range fires and roads have destroyed native vegetation and provided pathways for invasive species such as cheat

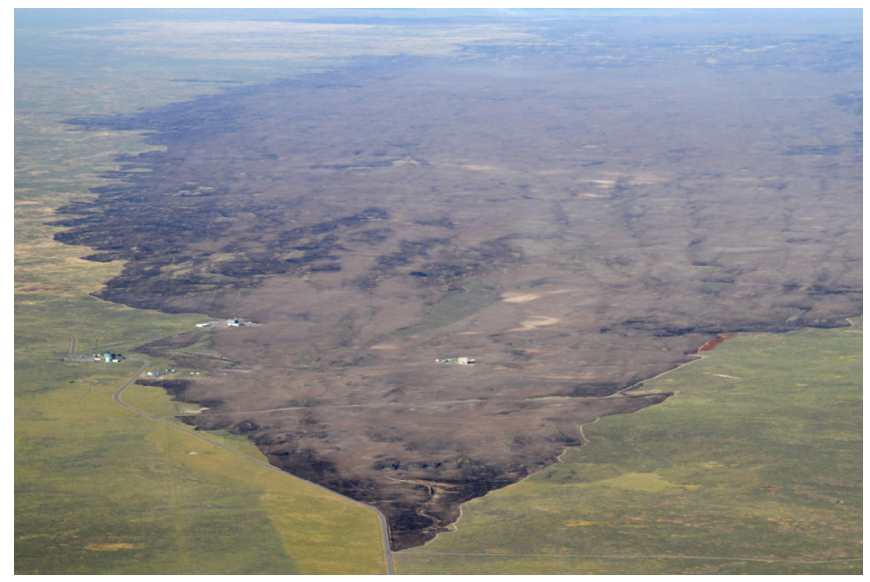

Figure 6. Aerial view of 2010 Jefferson fire in relationship to the CITRC area. grass. Riparian plant communities, dominated by willow, wild rose, and large cottonwood trees, existed until relatively recent times, but they have generally not survived modern cycles of drought and upstream water diversion.

Toward the end of the Pleistocene a number of large faunal species such as mammoth and camel became extinct and during more recent times, species such as bison have also disappeared from the Snake River Plain and INL region. Modern INL faunal communities consist of terrestrial vertebrate species such as pronghorn, deer, elk, coyote, badger and fox, along with numerous small mammals such as rabbits, mice, voles, bats, and ground squirrels. Reptilian species include a number of lizard species, the most abundant of which is the sagebrush lizard. Four species of snake are known to inhabit the area as well. These include the gopher snake, the western garter snake, the desert striped whipsnake, and western rattlesnake (Sehman and Linder 1976). Avian species are largely migratory, although sage grouse reside in the area yearround. During wet years, the "Sink" areas provide a temporary haven for many species of migratory waterfowl. Birds of prey, including owls, hawks, eagles, and falcons (Craig and Trost 1976) also occupy the INL area on a seasonal basis.

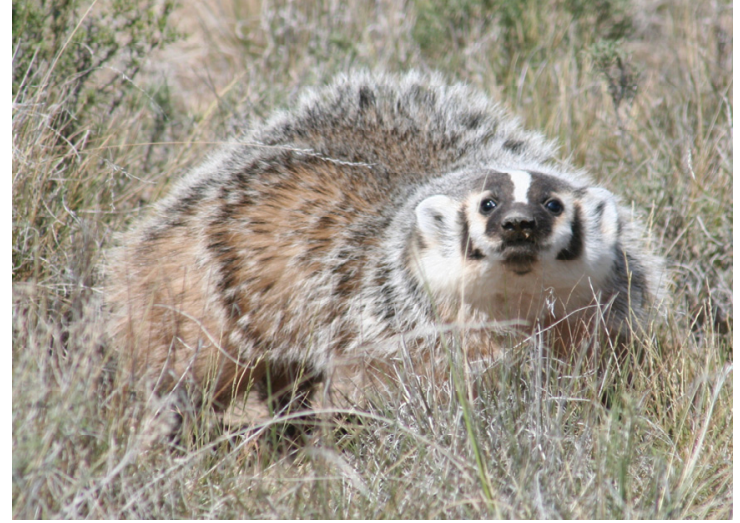

Figure 7. A curious badger. 


\subsection{INL Culture History}

The Pioneer Basin and surrounding lava uplands are part of the northern Great Basin Culture Area and a stage on which at least 13,500 years of human history has played out in an intimate relationship

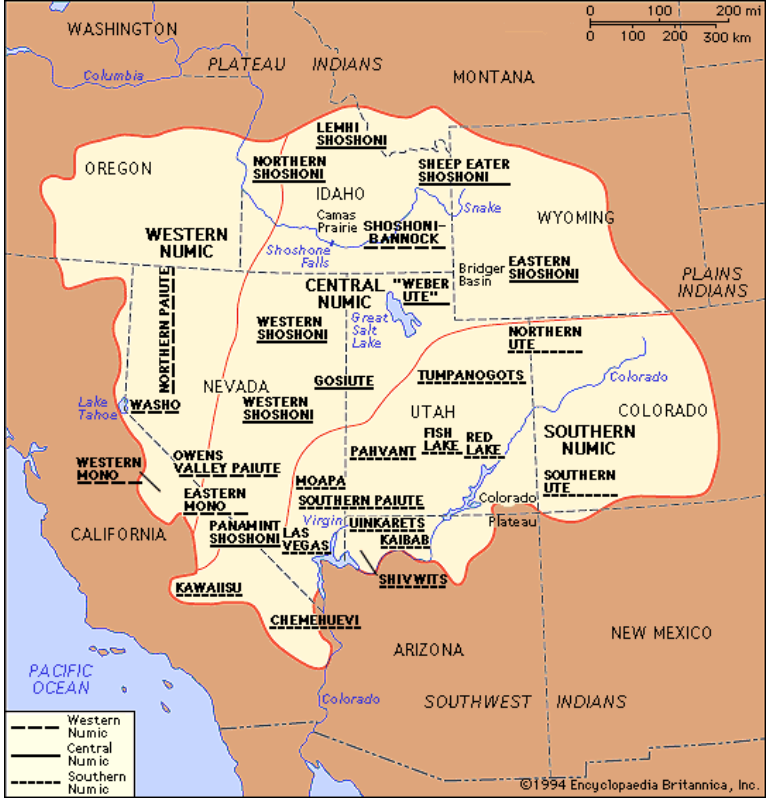

Figure 8. Great Basin Culture Area. with the natural environment. The wide variety of hunting implements and plant processing tools found on the INL attests to the ways in which human hunting and gathering populations adapted to changing conditions over time. Different technologies and foraging strategies were adopted as needed, enabling people to live in and productively use the seemingly bleak high desert environment. During initial European exploration, roads and trails were established and with the arrival of the railroad, a period of more focused settlement and landscape changes to support an agrarian lifestyle began. Water has always been a limiting factor in permanent settlement of the region, and overestimates of abundance combined with regular cycles of drought condemned most of these nineteenth and early twentieth century settlement attempts to failure. In modern times, the basic transportation infrastructure established by hopeful farmers and irrigation developers along with discovery of the Snake River Plain Aquifer, a vast source of underground water, enabled the U.S. government to establish one-of-a kind facilities at what is now known as the INL. Initially, these activities were devoted to wartime (World War II) efforts and later the lands became host to ground-breaking scientific research.

\subsubsection{Prehistoric Uses}

The relationship between aboriginal hunting and gathering populations and the INL landscape has the deepest roots of all human endeavors in the region, enduring for more than 13,000 years without fundamental change. Tangible evidence of this long term land use is ubiquitous, though not randomly distributed on the landscape. The subtleties expressed in the archaeological record are reflective of changes through time in the types of resources utilized and the manner in which they were harvested. At the end of the last Ice Age, or the Pleistocene, for example, settlement and subsistence appear to have been strongly tied to rivers and marshes, including the marshy edges of Lake Terreton (Marler 2004; see Section 6). Water continued to play an important role in settlement and subsistence choices later during the dryer conditions of the Holocene (approx. 11,500 years ago) and during a wetter interval when Lake Terreton may have partially filled (Bright and Davis 1982), high vantage points appear to have been intentionally utilized, perhaps because of the commanding view that they provided of the surrounding area (Pace and

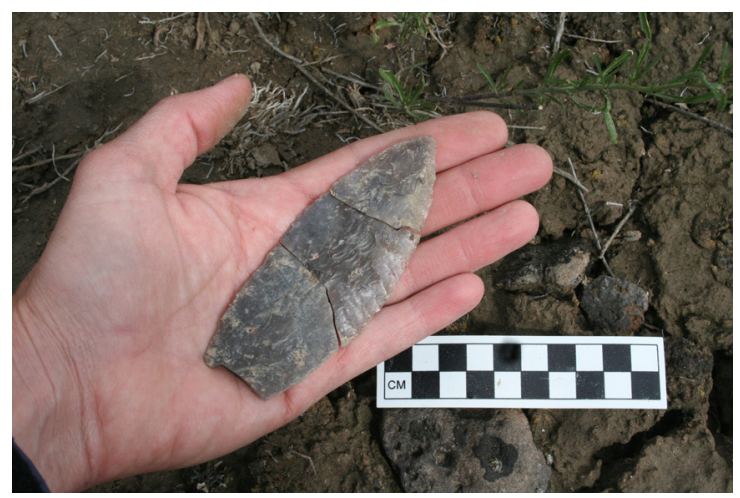

Figure 9. A potential Clovis preform found during a Section 106 project near NRF. Henrikson 2006, Pace 2007). 
Throughout the lengthy period of prehistoric use, the overall lifeway of hunting and gathering appears to have remained consistent as reflected by artifact assemblages recorded at nearly 3,000 archaeological resources found during cultural resource inventories. To date, approximately $10 \%$ of the Site has been surveyed for archaeological resources. A predictive model developed to facilitate long-term project planning and ongoing protection of this legacy have provided estimates of as many as 75,000 additional prehistoric archaeological locations that could exist within the INL Site boundaries (Ringe 1995, Plager et al. 2004).

\subsubsection{Historic Uses}

Since the early 1800 s, Euro-American presence has been felt on what is now the INL Site. Initially, land-use was light and transient, perhaps much like that of the early Native American occupants. Like those earlier people, the first Euro-American occupants were intent on resource extraction. However, unlike the earlier inhabitants, whose focus was on food to sustain life, some Euro-Americans trapped beaver and other animals for monetary purposes. In 1852, Goodale's Cutoff was established as a northern extension of the Oregon Trail; an alternate route to reach the rich resources of the Oregon Territory. Still, this was transient activity, and the human imprint on the landscape remained modest.

Between 1860 and 1880, Goodale's Cutoff came to be used to trail cattle and eventually sheep, from western ranges in Oregon, Washington, and Idaho to eastern markets. During this same time period the mining industry in the mountains of Central Idaho boomed and a number of wagon and stage roads were established between growing towns and cities along the Snake River and the mining camps of the interior. Many of these roads, including a portion of Goodale's Cutoff, crossed the INL Site and several continue in use today. By the early 1880 s, a number of ranching operations were underway at the north end of the INL near Howe and around the Big and Little Lost Rivers and the Birch Creek Sinks. Cattle were routinely herded across the Site from these areas to summer range near Big Southern Butte (DOE-ID 2011; Gerard 1982).

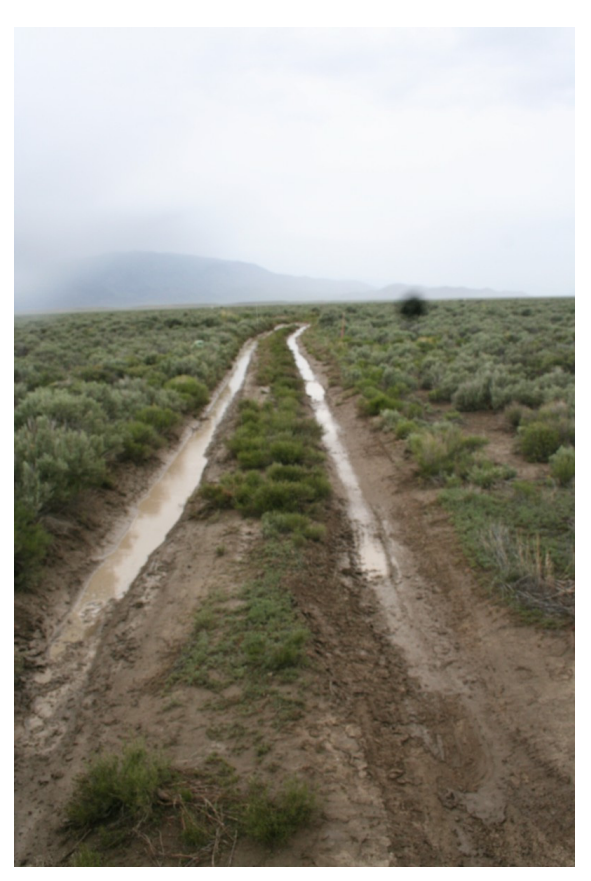

Figure 10. Impassable historic stage road (T-5) after a Spring thunderstorm.
While the appearance of Euro-Americans began on and near the INL Site in the early 1800 s, it wasn't until passage of the Carey Land Act in 1894, and particularly the 1902 Reclamation Act, also called the Newlands Act, that homesteading efforts on these arid lands began in earnest. Most of these homesteads were located along the Big Lost River and in the Mud Lake region. Between 1905 and 1920 a number of water-control projects including the Mackay Dam and numerous irrigation canal systems were constructed. The town of Powell was established adjacent to the Oregon Shortline railroad, which was established in 1901, and the Big Lost River near what is now the Radioactive Waste Management Complex (RWMC) in the southwest corner of the INL. A second townsite, known as McCullum, was planned some distance to the north. An extensive irrigation system extends and radiates from the Big Lost River across the entire INL. Overgrown and barely discernible field scars are also associated with homesteads and irrigation features.

Although irrigation projects in the Mud Lake area were successful, irrigation efforts and related homesteading activities associated with the Big Lost 
River on the INL Site area failed due to insufficient water and were essentially abandoned by the mid1920s. In addition to roads and canal systems, artifacts from the 1800s and early 1900s include the remnants of stagecoach stations and homesteading activity such as foundations, domestic items, and children's toys that give insight into the daily lives of the early pioneers. Over 100 historic archaeological sites have been recorded from this period with hundreds more awaiting identification and recordation. At many of these sites, careful INL CRMO research has enriched the archaeological evidence by the discovery of associated archival materials including official homesteading and irrigation company records, family photographs and documents, and interviews with descendents of the early pioneers (see Section 6).

\subsubsection{Arco Naval Proving Ground}

With the outbreak of World War II (WWII), Pocatello, Idaho, was selected as a location to construct an ordnance plant with a mission to reline and test Pacific Fleet naval armament. Shortly after plant construction was completed, the Arco Naval Proving Ground (ANPG) was established on core lands that would eventually become the INL Site, to test the relined guns. Beginning late in 1942, testing began and during the course of the War, all manner of ship weaponry, from anti-aircraft guns firing 3-in. rounds to the main battleship 16-in. guns were test-fired at the ANPG. The latter fired 2,800-pound test rounds from the Scoville railroad siding (now the Central Facilities Area [CFA]) as far as 20 miles to the north.

After the end of WWII, the ANPG continued its mission to test various kinds of conventional explosive ordnance. The post-war tests were designed to explore storage and transport methods to minimize the land area needed for storage and the potential for sympathetic explosions. Artifacts remaining from the WWII period are concentrated at CFA, south of Highway 20 near the buttes and the Big Lost River, and in a wide firing fan that extends from CFA to the northeast. At CFA, resources include buildings like the brick bungalow that once served as quarters for a naval officer and his family, structures like concrete gun mounts and an 8 -ft. thick concussion wall with an observation tower that looms above, equipment such as the gantry crane that unloaded all manner of weaponry and ordnance, and a landscape of roads, trees, and flowerbeds. In outlying areas, concrete targets, small observation towers, craters, and unexploded ordnance reflect work activities while discarded domestic items from extensive trash dumps provide unique insight into the lives of military

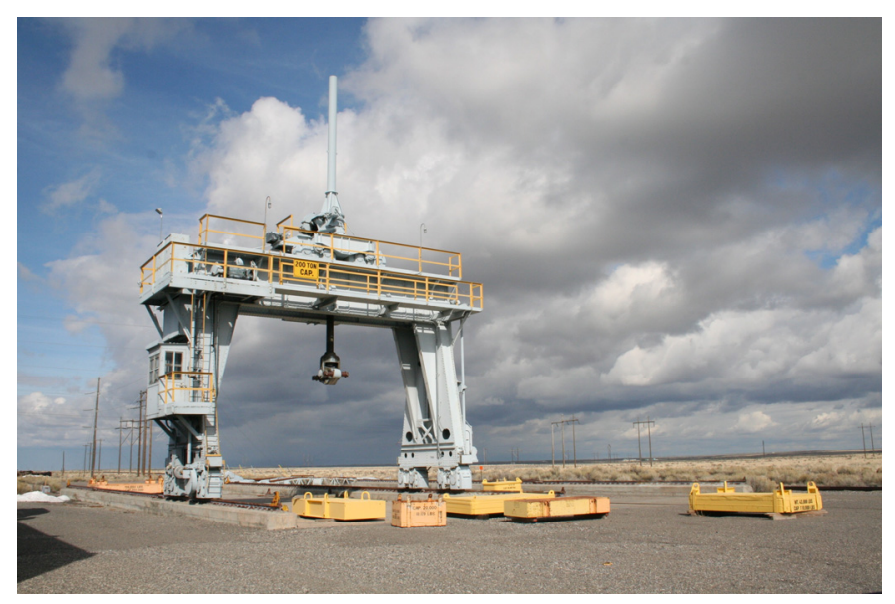

Figure 11. 1943 gantry crane used to offload guns used by the Pacific Naval Fleet.

personnel and civilian ordnance workers and their families.

\subsubsection{National Reactor Testing Station}

In 1949, the newly established U.S. Atomic Energy Commission (AEC) selected the ANPG as the location to build and test the nation's nuclear reactors. Land transfers between the Department of Defense and the AEC were concluded, private properties were acquired, and the National Reactor Testing Station (NRTS) was established. Later that year, and again in the early 1950s, additional land was acquired that brought the facility close to its current 890 square miles. The purpose of the NRTS was to provide an isolated location where prototype nuclear reactors could be designed, built, and tested. The Site was renamed the Idaho National Engineering Laboratory (INEL) in 1974, and renamed again in 1997 as the 
Idaho National Engineering and Environmental Laboratory (INEEL). In February of 2005 it became the Idaho National Laboratory (DOE-ID 2011).

Since its establishment, 52 "first-of-a kind" reactors and associated support structures have been constructed at the NRTS/INEL/INEEL/INL. Ground-breaking research fundamental to the development of nuclear power generation and nuclear propulsion has been conducted at the nine facilities that remain active today and at others that have undergone decontamination, deactivation, and demolition (DD\&D). In 1966, in recognition of one aspect of the INL's scientific heritage, Experimental Breeder Reactor I was recognized as a National Historic Landmark and listed in the National Register of Historic Places. Present and future Laboratory missions include development of the next generation of nuclear technology for power reactors, development and testing of national security technologies, and maintenance and expansion of a multi-program national research laboratory role. To meet these goals, INL Site facilities were consolidated into three primary areas including the Advanced Test Reactor Complex (formerly the Test Reactor Area), the Materials and Fuels Complex (formerly Argonne National Laboratory-West), and the Research and Education Complex (REC), a group of offices and laboratories in Idaho Falls.

Environmental cleanup, including a significant DD\&D effort comprise another important current mission with ongoing effects to historically significant INL properties.

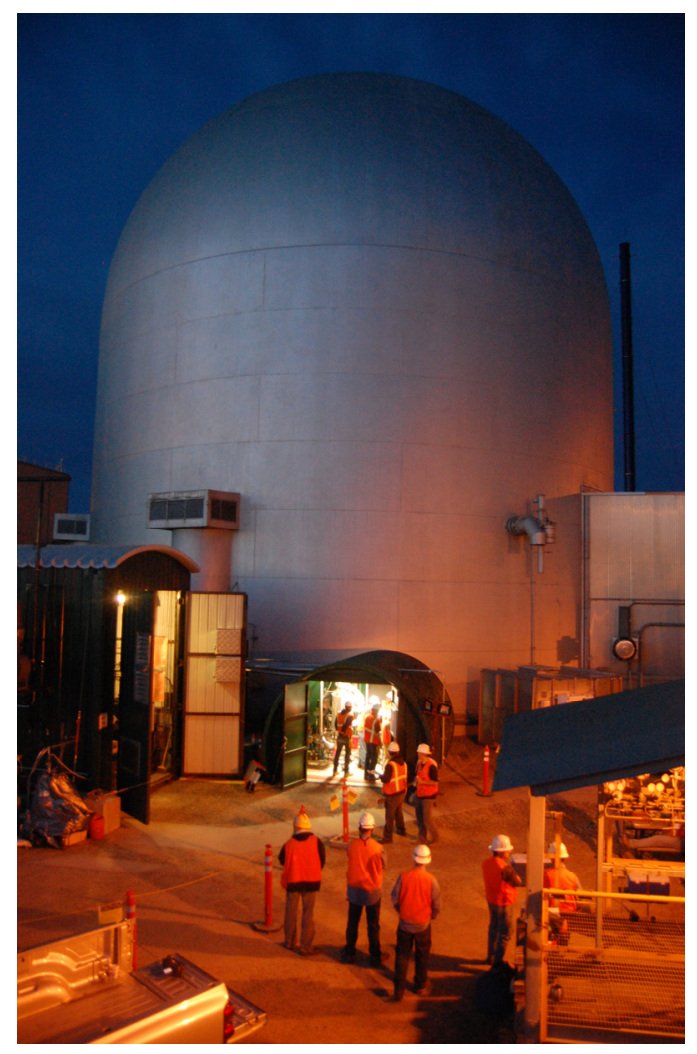

Figure 12. EBR-II under demolition.

INL building inventories include over 300 historic properties, including Experimental Breeder Reactor I (EBR I), INL's only National Historic Landmark, and others like the CFA World War II structures, considered to be "signature" properties in the history of the INL. Most INL buildings have been modified and used for a variety of projects and programs through the years, but still retain historical significance. Indeed, change has been a constant in the architectural history of the Laboratory, perhaps as a partial reflection of the focus on function over style, the process of scientific discovery itself, and the fundamental role that INL facilities have filled in the advancement of nuclear research (Braun 2006a).

Today, many historic buildings have been demolished or are planned for demolition. Prior to the start of any activities that would cause adverse impacts; photographic and documentary evidence is assembled, often in Historic American Engineering Record (HAER) reports, to preserve an archival record of the important scientific achievements that have occurred (see Section 9). The INL CRMO curates many of these records and other data in a central archive, appropriately called the INL Archive Center (IAC). To assist present and future researchers, indices are also being developed to facilitate access to important archival data (i.e., photographs, technical reports) housed at the IAC and elsewhere. Additionally, INL is home to important nuclear era artifacts, which include items such as prototype nuclear-powered jet engines, a lead shielded locomotive, control panels, and scale models. The EBR I Visitors Center displays some of these items while others await the identification of a permanent curatorial center. 


\subsubsection{Contemporary Resources and Values}

Tangible evidence of the past such as lithic artifacts, prehistoric campsites, historic trails, homesteads, World War II, post-war and pioneering nuclear-era buildings, structures, and archives such as those described above comprise one form of cultural resource at the INL. A second, equally important form is more ethereal and less easily defined. These resources generally consist of cultural and natural places, landscapes, viewsheds, select natural resources, and sacred areas or objects that have importance for Native Americans and others such as the descendents of early pioneers and homesteaders. Ongoing consultation with these groups is facilitating the identification and protection of these less tangible cultural resources.

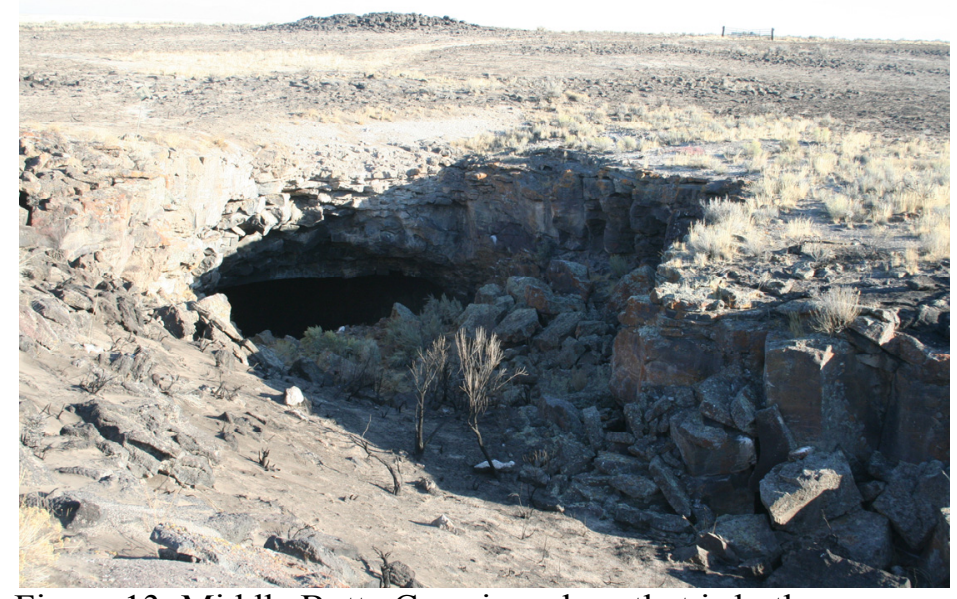

Figure 13. Middle Butte Cave is a place that is both historically and prehistorically important. 


\section{PROGRAMMATIC FRAMEWORK}

A myriad of federal laws, regulations, and directives require federal agencies, like the DOE, to consider cultural resources in their ongoing operations. These requirements are broadly encapsulated in three primary federal laws; the National Environmental Policy Act of 1969 (NEPA 1969), the Archaeological Resource Protection Act of 1979 (ARPA 1979), and the National Historic Preservation Act of 1966 (NHPA 1966), as amended, and their implementing regulations. Summaries of all applicable requirements are provided in the INL CRMP (DOE-ID 2011).

Some elements of the INL CRMO compliance responsibility are prescriptive, for example the routine completion of archaeological surveys to identify cultural resources that may be impacted by proposed "undertakings" on INL lands or reviews of proposed modifications to INL structures (NEPA, NHPA Section 106). Other elements allow more latitude, for example the requirement that federal agencies, including DOE-ID at the INL, identify and assume responsibility for all historic properties under their jurisdiction (NHPA Section 110), not only those lying in the path of proposed development (NHPA Section 106) and requirements for conducting public outreach and education about archaeology (ARPA).

The substantive requirements of the pertinent legal drivers are streamlined and tailored to meet the unique needs of the INL and are presented in the INL CRMP (DOE-ID 2011). Reviewed and approved by the Idaho SHPO, Advisory Council on Historic Preservation, National Park Service, and ShoshoneBannock Tribes, this document includes standards for identification, evaluation, and protection and, when appropriate, mitigation of all types of INL cultural resources. Finalized in 2005, regular updates ensure its continued relevance. A Programmatic Agreement between the DOE-ID, Idaho SHPO, and Advisory Council on Historic Preservation implements and legitimizes the CRMP. Within the CRMP, historic contexts and research designs have been developed to guide National Register eligibility assessments, Section 110 activities, and public outreach and education. Broad conceptual themes such as: prehistoric settlement and subsistence, early historic exploration and discovery, fur trapping and trading, emigration, transportation, homesteading and irrigation, agriculture, ranching, ordnance testing, nuclear reactor testing, cold war weapons and military applications, commercial power reactor safety and design, chemical reprocessing, and remediation of waste provide the primary contexts under which research is conducted. For archaeological sites, problem domains such as: chronology, settlement and subsistence, cultural relationships, demography, environment, technology, and data recovery techniques are also addressed.

The INL CRMP (DOE-ID 2011) is an effective and efficient means to maintain compliance with regulatory drivers and implement DOE policies and procedures. The processes described in the Plan are designed to balance historic preservation with the fulfillment of primary INL missions as well as the need to clean up the environment while maintaining focus on the intent of the regulatory drivers, which is to preserve the important heritage contained within the INL Site boundaries. The Plan strives to create a balance between the past, present, and future. The INL CRMO prepares a summary report on a regular basis that describes the tasks completed toward the general goals contained within the CRMP. The high level summaries that follow provide DOE-ID, regulators, the Tribes, stakeholders, and interested parties with an opportunity to reflect on progress and provide direct feedback for future activities. This interaction is critical to ensure that the CRM program remains focused on the stewardship of INL cultural resources for the benefit of present and future generations. 


\section{INL CULTURAL RESOURCE PROGRAM PERSONNEL}

The INL CRM program is comprised of three entities: DOE-ID, the INL CRMO, and the Shoshone-Bannock Tribes' DOE Program. DOE-ID's Environmental Technical Support Division takes responsibility for general oversight of CRM activities through a designated Cultural Resources Coordinator. This individual is joined by DOE-ID's Tribal Liaison Officer from the Public Affairs Office, who in turn has lead responsibility for coordinating communications and interactions with the Shoshone-Bannock Tribes. The Tribal Liaison Officer also manages the DOE-ID funded Tribal DOE Program based at the Heritage Tribal Office (HeTO).

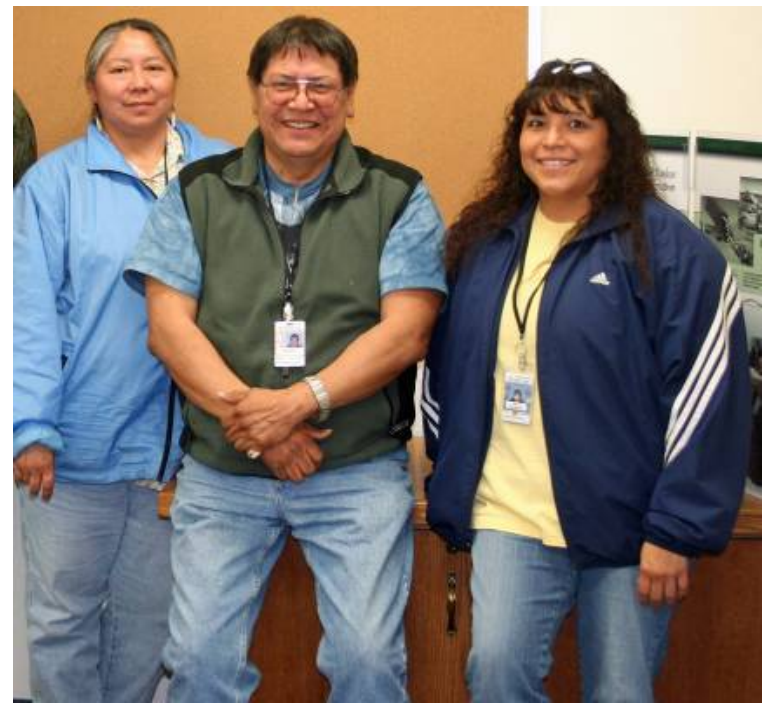

Figure 15. Caroline Boyer Smith, Willie Preacher, and LaRae Buckskin, Shoshone-Bannock HeTO.

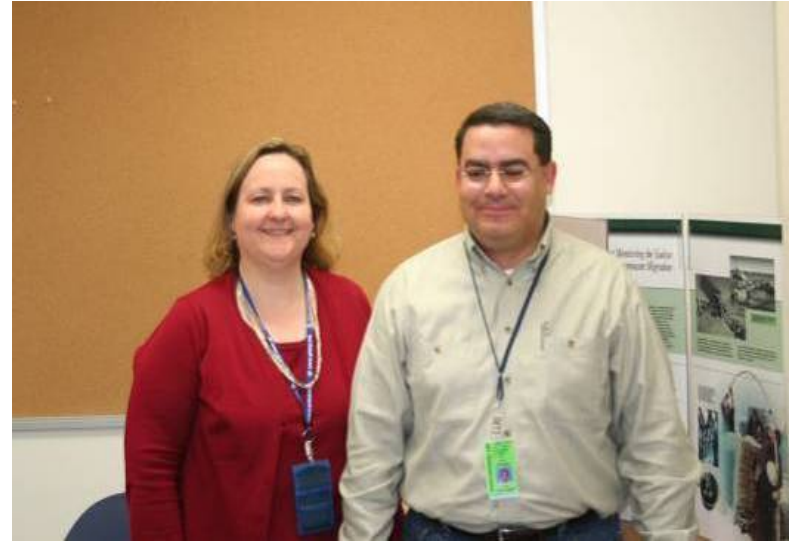

Figure 14. Teresa Perkins and Robert Gallegos, DOE-ID (Bob Pence not shown).

DOE-ID and the INL CRMO maintain a close cooperative relationship with the ShoshoneBannock Tribes per a written Agreement in Principle (AIP) (DOE-ID 2007). The Tribal DOE Program is overseen by a Program Director, who has broad responsibilities that include, among other things, implementation of the AIP through oversight of INL environmental programs, transportation safety, and cultural resource management. Technical specialists in the Shoshone-Bannock HeTO interact directly with INL CRMO staff and participate in many activities, providing valuable assistance and a unique holistic perspective that facilitates protection of both tangible and intangible INL cultural resources. 


\section{INL CRM CREW}

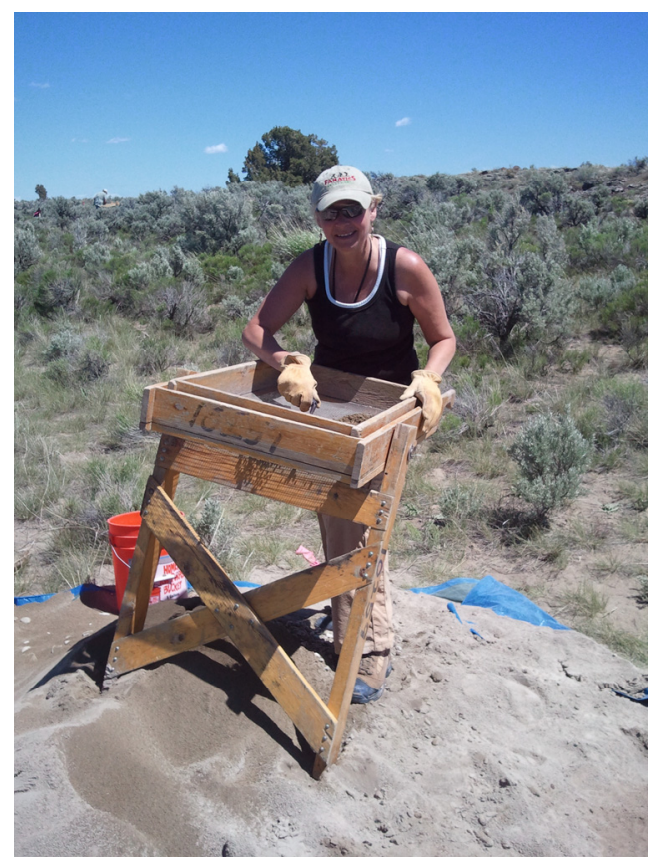

Figure 16. Julie Braun Williams

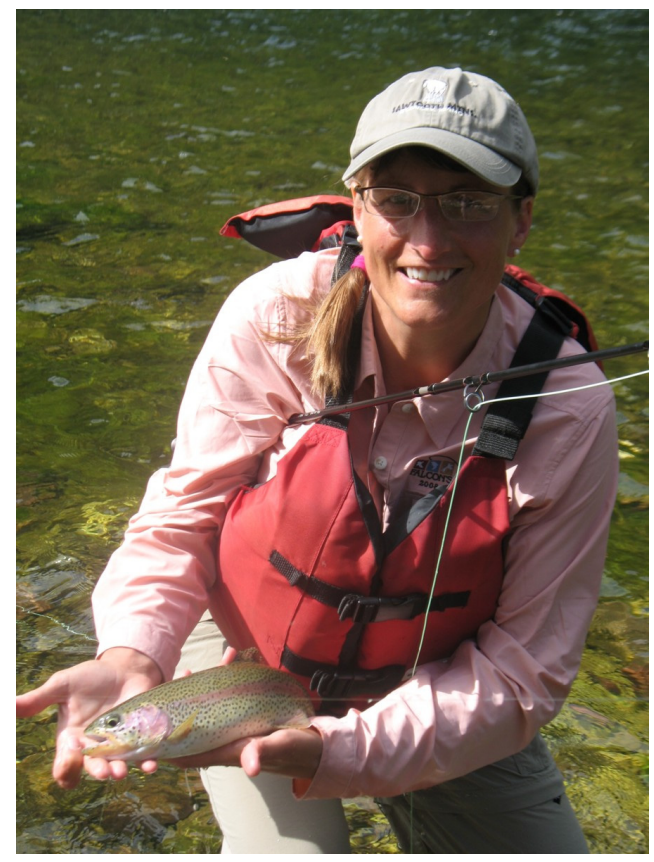

Figure 17. Brenda Ringe Pace
Julie is the Team Lead for the INL Cultural Resource Management Program. She has worked at the INL since 1990, specializing in historical and industrial archaeology, architectural history, and compliance with environmental and cultural resource laws and requirements in support of federal programs and projects. Julie is a fourth generation Idahoan who enjoys managing her 2,200 acre cattle ranch where she spends most of her free time camping and fishing. Julie holds an M.A in Historic Preservation from Goucher College.
Brenda is a Registered Professional Archaeologist with 28 yrs experience in archaeology and cultural resource management, specializing in cultural resource compliance (NHPA, NEPA, ARPA, NAGPRA). Her research interests are prehistoric rock structures, predictive modeling of archaeological site locations and cultural landscapes. Her personal interests include fly fishing, river rafting, skiing, native plants, and needlework. Brenda has an M.A in Anthropology from Idaho State University. 


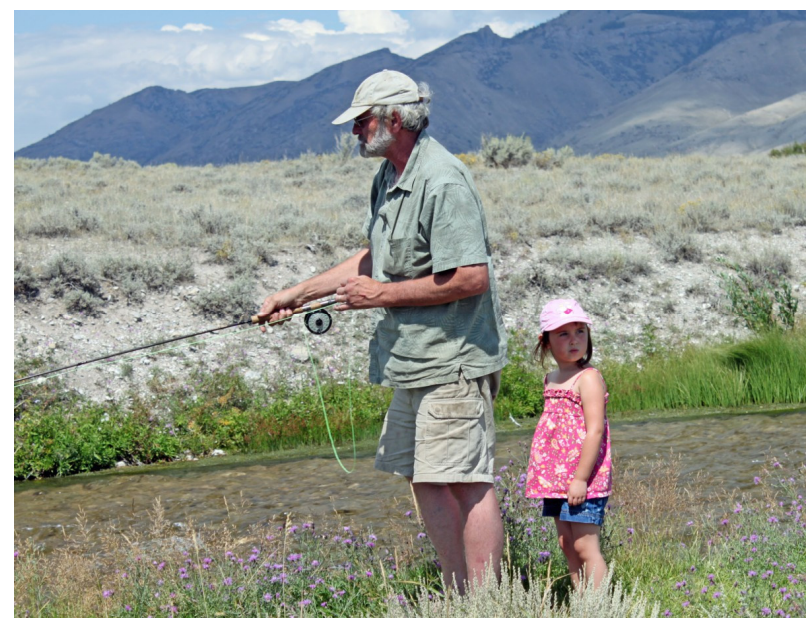

Figure 18. Clayton F. Marler

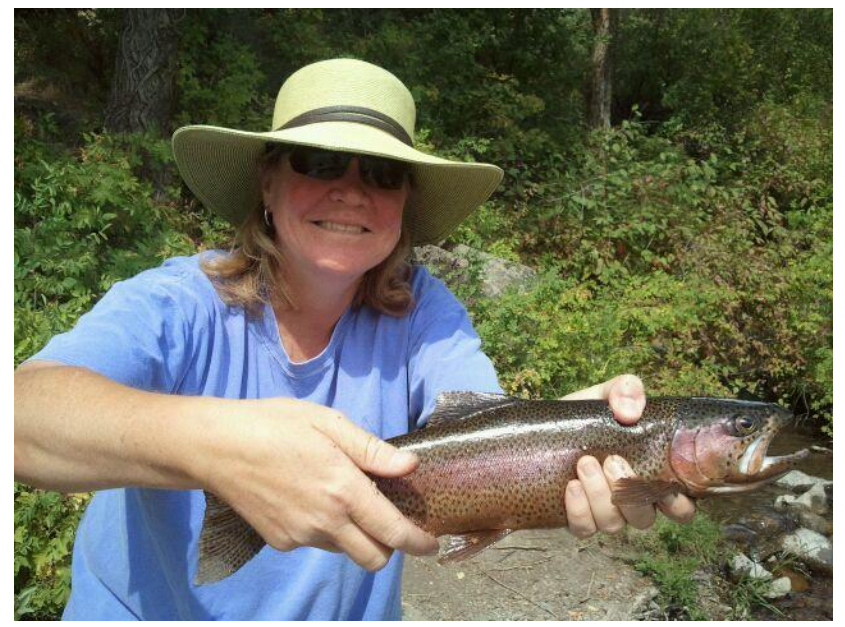

Figure 19. Hollie K. Gilbert

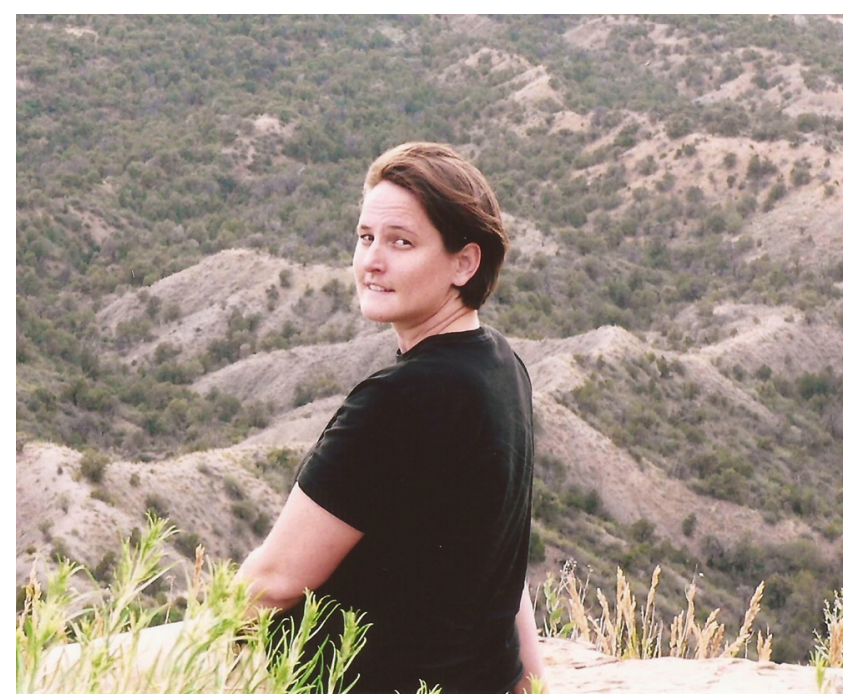

Figure 20. Christina L. Olson
Clayton has almost 40 years experience in Southwestern and Great Basin archaeology and Cultural Resource Management. His research interests are presently focused on human adaptations during the terminal Pleistocene/early Holocene timeframe and X-Ray fluorescence analysis of obsidian artifacts to determine raw material sources. His personal interests include fishing, reading, and gardening but most importantly, he enjoys being a grandparent. Clayton has an M.S. in Anthropology from Idaho State University.

Hollie has over 13 years of professional cultural resource management experience and 26 years of technical experience at the INL. She specializes in historical archaeology where her research interests include regional stage stations, homesteaders and family history. Her personal interests include quilting, fishing, camping, geology and photography. Hollie holds an M.S. in Anthropology from Idaho State University.

Christina has over 10 years of professional experience as a historian and archivist. Her professional and research interests include American frontier expansion and settlement, $20^{\text {th }}$ century American architecture, Cold War Era history and international heritage site policy and management. Her personal interests encompass hiking, travel, and cinema. Christina has an M.A. in Historic Preservation from University of Georgia. 


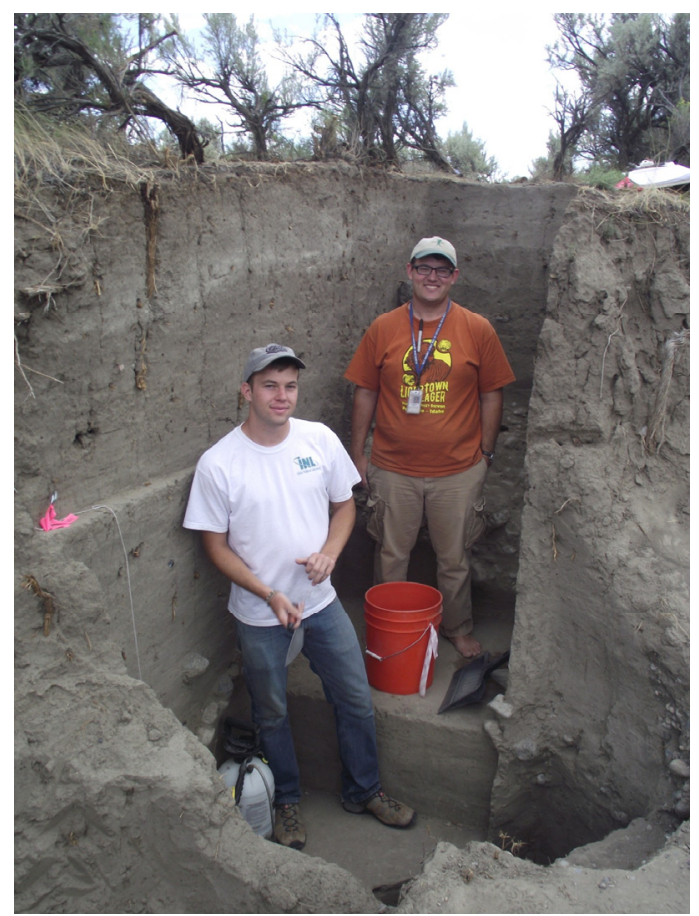

Figure 21. Cameron and Josh
For the second year, Cameron Brizzee and Joshua L. Keene spent their summer months as interns for the INL Cultural Resource Management program. Cameron is currently attending the University of Montana where he is seeking a B.A. in Information Management. Joshua is a PhD. Candidate at Texas A \& M University in the Anthropology department. 


\section{CULTURAL RESOURCE MANAGEMENT OFFICE ACTIVITIES \\ 5.1 Funding}

During fiscal year 2010, there were four types of funding that supported INL CRM work. "Direct" project funding is provided by specific projects or programs to support compliance with Section 106 of the NHPA. "Indirect," or overhead funding, was provided to accomplish crosscutting activities not associated with specific projects and to address the full range of regulatory drivers associated with cultural resources. The ICP contractor, $\mathrm{CH} 2 \mathrm{M}$ Hill/Washington Group International (CWI), provided funding through a Service Agreement with BEA to support those cultural resource milestones associated with accelerated cleanup and the Naval Reactors Facility provided funding to support cultural resource evaluations within their administrative area. INL CRM staff also served as subject matter experts on project teams based at Pacific Northwest National Laboratory in meeting regulatory requirements related to the permitting of new reactors for the U.S. Nuclear Regulatory Commission.

\subsection{Approach}

Cultural resource management on the INL is a dynamic process with some short-term goals and activities being accomplished each year in support of the overarching management goals of identification, evaluation, and resource protection and preservation as described in the INL CRMP. As specific tasks are accomplished or goals achieved, they might be dropped from the list while others might become ongoing activities. New goals and tasks are added in response to changing conditions at the INL Site and within the regulatory framework that drives compliance activities, and in consideration of comments and advice from stakeholders. Goal implementation and completion is funding dependent.

There are ten long-term goals for the INL CRM program with a variety of ongoing and recurring tasks associated with each goal.

\section{Goal 1: Identify and Manage INL Cultural Resources}

- Task 1. Reevaluate and update program requirements

- $\quad$ Task 2. Seek and maintain preservation partners

- Task 4. Inventory and record INL cultural resources

- Task 5. Maintain program and project files and records, electronic databases, and GIS data

- $\quad$ Task 6. Conduct oral histories

\section{Goal 2: Evaluate INL Properties for Historic Significance}

- Task 1. Conduct research to develop and update prehistoric and historic contexts required to identify themes and establish the relative importance and National Register eligibility of specific resources.

- Task 2. Prepare National Register of Historic Places nomination documentation as requested by DOE-ID.

\section{Goal 3: Monitor the Condition of INL Cultural Resources}

- Task 1. Establish baseline condition of select INL cultural resources

- Task 2. Assess condition of select INL cultural resources, including at a minimum, Aviators' Cave, Prickly Cave, Middle Butte Cave, and WERF burial (10-BT-2046)

- $\quad$ Task 3. Collect data for yearly report (Routine visits to archaeological sites and project-specific visits). 


\section{Goal 4: Protect INL Cultural Resources}

- Task 1. Participate in legal and regulatory reviews of INL documents and policies to ensure integration and maximize effectiveness of overall regulatory compliance

- Task 2. Respond to unanticipated discovery of cultural resources

- Task 3. Review, approve, and archive external investigator permits and data use agreements and oversee subcontracts

- Task 4. Establish and maintain INL Archive Center by gathering and archiving, using professional standards, INL historical data (i.e., photographs, architectural drawings, maps) and make data readily accessible

- Task 5. Develop and implement specific site protection and stabilization plans, as needed.

\section{Goal 5: INL Artifact Curation}

- Task 1. Prepare pre-1942 artifacts in INL interim storage and associated documentation for accession into an accredited curatorial facility

- Task 2. Ensure security of artifacts and associated documentation in interim INL storage

- Task 3. Review and coordinate requests for use of INL artifact collections

- Task 4. Prepare for and participate in annual inspection of curatorial facilities.

Goal 6: Stakeholder Involvement/Public Outreach

- Task 1. Participate in educational outreach programs (i.e., INL Speakers Bureau, Science Expo, Idaho Historic Preservation Month)

- Task 2. Coordinate and conduct public and employee tours of cultural resource sites

- Task 3. Present information on INL cultural resources and prehistoric and historic contexts

- Task 4. Host and conduct annual stakeholder meeting to report on previous fiscal year activities

- Task 5. Present at professional events (i.e., conferences, meetings)

- Task 6. Publish peer-reviewed articles.

\section{Goal 7: Interact with Native Americans}

- Task 1. Comply with cultural resource-related stipulations in the Agreement in Principle between DOE-ID and Shoshone-Bannock Tribes

- Task 2. Participate in regular Cultural Resource Working Group meetings

- Task 3. Invite Sho-Ban Heritage Tribal Office (HeTO) representatives to participate in archaeological fieldwork when possible.

\section{Goal 8: Conduct Work Safely}

- Task 1. Hold pre-job briefings to identify and discuss hazard mitigation

- Task 2. Inspect equipment regularly

- Task 3. Conform to all ISMS requirements

- Task 4. Comply with all field requirements.

\section{Goal 9: Maintain Professional Qualifications and Relationships}

- Task 1. Identify and attend training to enhance/maintain skills 
- Task 2. Maintain memberships in professional societies and organizations, interact with other cultural resource professionals (i.e., State Historic Preservation Office, National Park Service, professionals at other DOE labs).

\section{Goal 10: Activities Reports/Plans}

- Task 1. Complete annual report of activities

- Task 2. Complete annual Dept. of Interior questionnaire (Contract Deliverables Requirements List [CDRL] F.45)

- $\quad$ Task 3. Complete annual monitoring report (CDRL F.46)

- Task 4. Complete regular reports to Shoshone-Bannock HeTO

- Task 5. Update the INL Cultural Resource Management Plan, as needed (CDRL F.47)

- Task 6. As requested by DOE-ID, prepare and submit to DOE-ID a NRHP nomination package for a significant INL cultural resource (CDRL F.48).

\subsection{FY 2010 Highlights}

Each year performance measures in the form of specific milestones related to the general activities discussed above are selected to guide work activities and gauge programmatic effectiveness. In FY 2010, the CRMO successfully completed all formal deliverables including the following:

- Annual Site Monitoring Report (INL/EXT-10-20270);

- INL input to the annual Secretary of the Interior's Questionnaire on the Federal Archaeology Program (Williams 2010) Web page for links to these annual reports https://homer.ornl.gov/nuclearsafety/nsea/oepa/cultural/);

- Annual Report of Activities (INL/EXT-10-18783)

- Twenty-five tours of select INL cultural resources; and

- Annual stakeholder meetings.

In addition to satisfactorily completing formal deliverables the CRMO staff drafted the nomination package for, and assisted the DOE-ID Cultural Resource Coordinator, with getting Aviator's Cave listed on the National Register of Historic Places. Programmatic and project inventories and surveys also occurred in FY 2010. These activities are described in detail below.

- Field activities in FY 2010 were dominated by a few larger archaeological inventories completed to assess the potential impacts of ground disturbing projects under Section 106

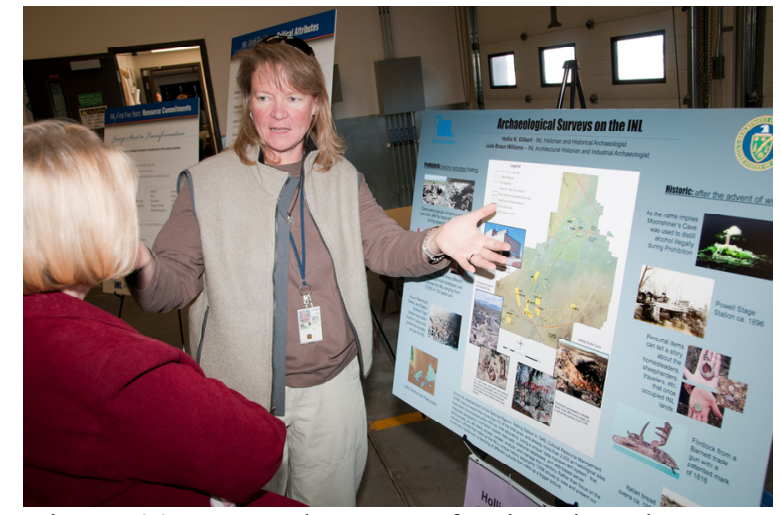

Figure 22. Internal INL professional exchange presentation. of the NHPA (see Section 9), NHPA Section 110 excavations (see Section 6), and routine monitoring of particularly sensitive localities (see Section 10). The most interesting Section 106 work of the year involved areas that had never been intensively surveyed for cultural resources. A variety of previously unknown prehistoric and historic archaeological sites were documented in proposed new training ranges, along a proposed new orientation for a major haul road, and within the proposed footprint of a new facility. 
- Section 110 field excavations in FY 2010 involved the recording of newly discovered resources from both prehistoric and historic time periods and provided opportunities for INL CRMO staff to conduct professionally stimulating research. The diverse inventories and refined classifications resulting from these projects are beneficial to the CRM program as a whole and the resulting publications and presentations at professional conferences enhance the professional standing of the INL. Tribal counterparts were also involved in the recording of many of these resources. The sharing of information between INL CRMO staff and tribal counterparts helps to refine the holistic view of cultural resources that is central to CRM at the INL and addressed in law, regulation, and DOE policy (see Section 8).

- Preservation of INL's modern history was furthered during the FY 2010 timeframe by continued development of the INL Archive Center, where important data such as photographs, engineered drawings, and key documents will reside and be made available for researchers. An INL archivist was hired in late FY 2010 to oversee the archival collection (see Section 9).

- As in previous years, INL CRMO participation in tours and various educational events proved to be enjoyable for all (see Section 7). 


\section{NHPA SECTION 110 PROJECTS}

Section 110 of the National Historic Preservation Act (NHPA) directs federal agencies to identify, evaluate, and nominate historic properties for which they have responsibility to the National Register of Historic Places and to manage those properties in a manner that considers their protection and preservation. The purpose of NHPA Section 110 is to provide statutory emphasis as well as intellectual guidance to establish a program whose aim is not only to protect resources but also to achieve enhanced understanding of human history.

In addition to meeting compliance requirements and research goals, a common thread through all of the INL CRMO Section 110 projects is a commitment to partnerships. Developing synergistic relationships with fellow INL scientists along with students and researchers from regional museums and universities enriches

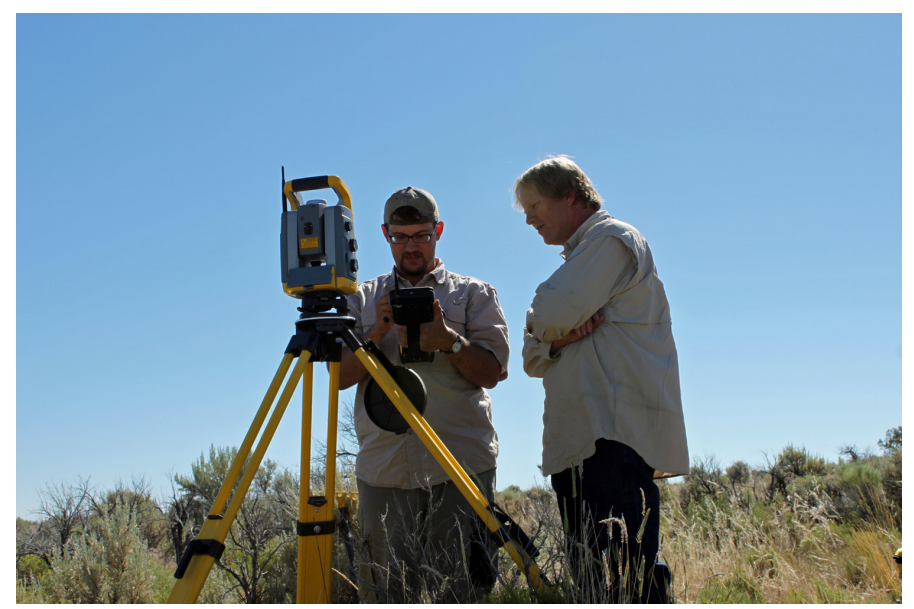

Figure 23. Mapping a Section 110 project site. thought, creativity, and intellectual rigor. These relationships help clarify the current regionally important research questions, and in return the INL provides a unique, relatively well-protected "outdoor laboratory" and extensive archives with which to seek ways to answer those questions.

The archaeological sites, historic architectural properties, traditional cultural areas, sacred Native American sites, natural resources, and INL facilities that define the INL landscape are integrated aspects of larger human systems adapted to the high-desert landscape of southeastern Idaho that have been operational for at least the past 13,500 years. CRMO Section 110 projects are selected to address research questions about how humans have used this landscape, how and why land-use has changed through time, and the role of technology in the changes that have occurred. In FY 2010, INL CRMO Section 110 projects included four emphasis areas: human riparian and marshland adaptations in the high desert, INL archival data, CRM files, and the Oral History project.

\subsection{Human Riverine and Lacustrine Adaptations}

Understanding how natural environmental systems have changed through time and how human systems adapt to those changes, either by changing lifestyles or by changing the environment itself (intentional or inadvertent) is becoming increasingly important in the $21^{\text {st }}$ Century. This multi-year Section 110 project is intended to explore specific human adaptations to relatively resource-rich aquatic environments in the eastern Snake River Plain high desert. Of particular interest is understanding if, and how land and resource-use may have changed through time in response to changing environmental conditions. Previous research (Marler 2004) has shown statistically significant changes in archaeological site distribution from the Late Pleistocene to the Early Holocene. Multiple, likely interrelated explanations for these changes exist but certainly Holocene warming trends and declining effective atmospheric moisture affected diet breadth, land use decisions and mobility patterns. Research goals include efforts to determine if additional patterned changes can be discerned from the archaeological record throughout the Holocene and reciprocally, to explore the extent to which archaeological site distribution data can help us understand changing paleo-environments. 
With sufficient surface survey data in hand a new phase of investigations was begun in 2010 . Clearer understanding of prehistoric lifeways and responses to shifting climatic situations requires careful excavation of select localities that contain deeply buried sequential cultural horizons. As a means to identify such locations a testing program was begun. In 2010 two potential locations situated near the Big Lost River were intensively tested. Although analyses are incomplete, at least one of those locations appears to have potential to answer significant research questions. Additional sites will be tested in 2011. Future goals also include site assemblage comparative studies to determine, among other things, if there is a distinctive "wetland toolkit". For example, are ground stone tools suitable for plant or seed processing more commonly found along playa or river shorelines than elsewhere? Intuitively the answer is "yes" but additional data are needed to confirm this. Eventually the research focus may also be expanded to include exploration of the subsistence role that the multitude of small playas that exist on the INL may have played.

In addition to research, this project is intended to provide training opportunities for students and to help build/maintain lasting collaborative relationships with universities, other INL researchers, and the Shoshone Bannock Tribes. In past years the project benefitted from the participation of Idaho State University archaeological field schools. In 2011 a PhD candidate from Texas A \& M University specializing in Geoarchaeology will return as a primary contributor to this project.

\subsection{INL Archive Center and CRM Project Files}

As a Federal agency, INL is mandated by Federal Regulation 36 CFR $\S 1220.10$ to establish and maintain a records management program that complies with National Archives and Records Administration (NARA) guidelines and disposition schedules. Primary responsibility of the records management program, and for the retention and preservation of official DOE-ID records related to INL, is provided for by support service organizations. Many active records with significant historic value are maintained at INL facilities and include such materials as photographic negatives and prints, architectural and engineering drawings, extensive library holdings that include technical and nontechnical reports and documents, oral histories, and other historical INL data.

In 2010, the acquisition, selection, and rough processing of architectural and engineering drawings from MFC, as well as various public relations items produced by the INL communications group and intra-company newsletters created by INL contractors, continued. In addition, an archivist was hired in September 2010, and the INL CRM Office began drafting a formal INL Archive Management Plan to identify and manage the important, irreplaceable information represented by INL archival materials. The goal of this Plan is to preserve all of the records, both at INL (active records) and in permanent federal storage at NARA-approved centers in Seattle, WA, and Washington, DC (inactive records).

Collections of information related to INL cultural resources are also significant and provide an invaluable resource to INL project and program managers and others. Some efforts in the Cultural Resource Project Files are ongoing, such as data entry of archaeological and historic architectural information collected from cultural resources in the field and facility areas, updates to geographical information system (GIS) coverages, and quality reviews of information already entered into the INL CRMO Data Management System.

\subsection{Oral History Project}

In FY 2010, the INL CRM Oral History project became a priority of the INL Archives and Special Collections. Since September 2010 the INL archivist has worked with the CRMO and INL employees to identify potential oral history subjects. In addition, collaborative information and brainstorming sessions have been initiated by the archivist between Records Management, the Technical Library, and the communications group to identify potential digital storage and platforms for appropriate dissemination of 
oral histories. The Oral History project has also become associated with the Knowledge Capture Community of Practice (CoP), with the archivist becoming a member of the $\mathrm{CoP}$, to further identify means to preserve the intangible history of the INL.

Also in FY 2010, DOE-ID funded a subcontractor to complete a chronicle of INL's activities from 2000 to 2010. Oral histories were completed as an important part of this project and were conducted by subcontracted professional historians. Select portions of the oral histories will be included in the forthcoming book. INL CRMO staff members assisted DOE-ID with the chronicle's conception, coordination, layout, and review. The book is scheduled for completion in early FY 2012 and will complement "Proving the Principle: A History of the Idaho National Engineering and Environmental Laboratory, 1949-1999". 


\section{STAKEHOLDER AND PUBLIC OUTREACH}

As a federal agency, DOE-ID is required by a number of statutes, primarily the NHPA, to manage INL cultural resources in a spirit of stewardship for the citizens of the United States and to provide those citizens with information about their cultural resources and opportunities to become aware of and involved in their preservation and management. Systematic planning for public participation in INL cultural resource management helps to ensure that such information sharing and participation takes place routinely and productively and that public interests regarding resource preservation and interpretation are considered as the Laboratory executes its primary missions. The list of potential stakeholders is as varied as the resources themselves, including such diverse groups as local historical societies, museum associations, Oregon Trail enthusiasts, INL employees and retirees, historical and scientific researchers, Native American tribes, and the general public. Because of the government-to-government relationship between DOE-ID and the Shoshone-Bannock Tribes, tribal outreach and participation are discussed separately in Section 8.

During FY 2010, communication strategies were implemented through a variety of tours, presentations, publications, educational events and participation in local and regional archaeological and historic preservation activities. All are briefly outlined in the following sections.

\subsection{Tours}

Tours have proven to be one of the most effective and enjoyable public outreach tools for INL CRMO staff and participants alike. During FY 2010, twenty-five tours to INL cultural resource locations were provided to such diverse individuals and groups as the St. Anthony Rotary Club, Idaho State University Friends of Learning, ShoshoneBannock tribal members, INL interns, and DOE-ID managers. In addition, an annual public tour was conducted in May as a part of Idaho Archaeology and Historic Preservation

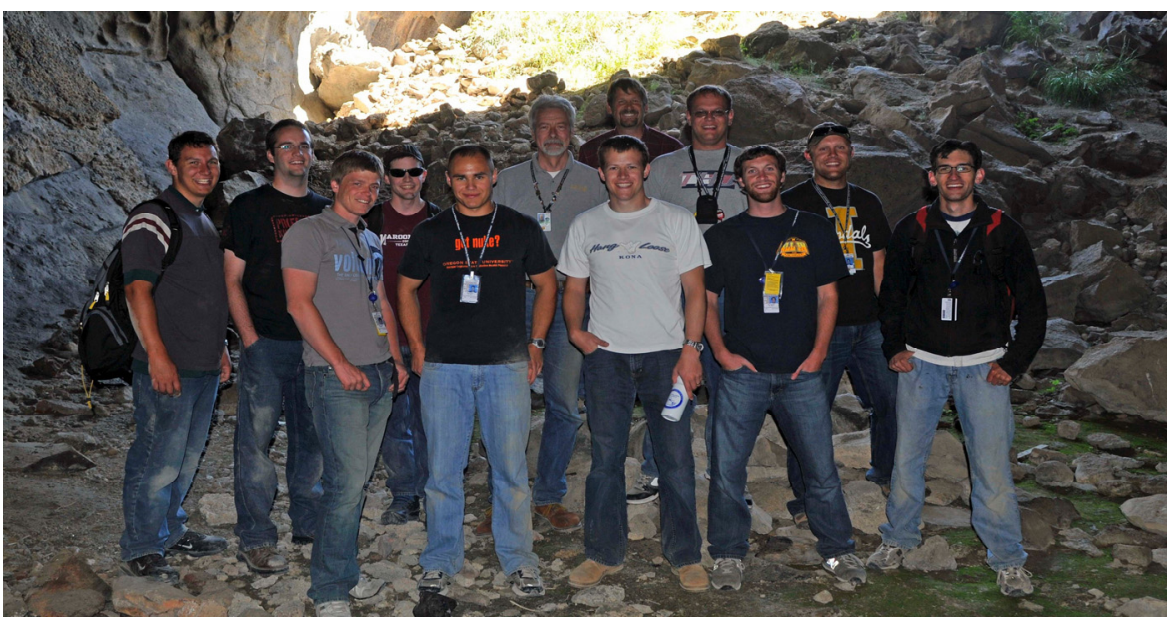

Figure 24. Nuclear engineering interns 2010 tour participants. Month activities. In 2010 an INL Communications Department staff member participated in the tour and subsequently published an article in Nucleus devoted to the tour experience and INL cultural resources.

\subsection{Presentations and Publications}

Groups requesting and receiving presentations in FY 2010 were as diverse as those requesting tours. INL CRMO staff visited schools, community groups, and other INL organizations as part of an ongoing program to share information about INL cultural resource management activities as well as knowledge about the cultural resources themselves. During the fiscal year, hundreds of interested INL employees and retirees, tribal members and elders, and members of the public were reached through these efforts. Groups who were provided with presentations ranged from a Korean delegation to the Pacific Northwest Archaeological Field School Executive Session participants. Internal presentations on Archaeological 
Resource Protection Act requirements were also provided to fieldworkers in several diverse organizations. Presentation topics included INL archaeology, history, resource management, careers in these disciplines, and safety in the field. A presentation on INL's historic structures at the international American Nuclear Society meeting in Idaho Falls garnered an invitation to present the same paper at the "Best of ANS DD\&R" meeting to be held in FY 2012 in Washington D.C.

\subsection{Professional Associations}

INL CRMO staff members individually conduct a variety of professional activities and serve in numerous capacities in local, regional, and national organizations. For example, individual memberships are maintained in various professional groups such as the Register of Professional Archaeologists, Society for American Archaeology, the Society for Historical Archaeology, the Society for Industrial Archaeology, the Idaho State Historical Society, the Idaho Professional Archaeological Council, the Idaho Archaeological Society, the Idaho Falls Historic Preservation Commission, the Oregon-California Trails Association, and Phi Alpha Theta Chi-Rho Chapter.

\subsection{Preservation Partnerships}

The INL CRMO is involved in a variety of productive partnerships with federal and state agencies, community organizations, and universities. CRMO staff members often volunteer their time to support research and public outreach activities. The reciprocal relationships developed through these efforts enhance INL CRMO abilities and help to maintain a network of professional contacts of value to the conduct of CRM on the INL. During FY 2010, INL CRMO staff continued their long-standing commitment to enhanced K-12 education through participation in local "Career Days" events and informational presentations to school groups. To fulfill DOE-ID's NHPA Section 110 responsibility in FY 2010, CRMO staff also engaged in a collaborative research project with Texas A\&M University. A $\mathrm{PhD}$ candidate in archaeology participated in the development of a research design that is being used to guide identification of Paleo-Indian sites on INL through the excavation of select locations.

An ongoing partnership exists between INL, the Idaho, Oregon, and Washington SHPOs, National Park Service, University of Oregon and various agencies and individual professionals in each state. Called the Pacific Northwest Archaeological Fieldschool, one CRM staff member serves on the executive committee to maintain and enhance the partnership. In addition, the DOE-HQ History Department selected five cultural resource management professionals from across the complex to serve as advisors to that program and an INL CRM staff member provides that service.

Portions of undeveloped range lands within the INL are under joint administration by DOE-ID and the Bureau of Land Management (i.e. grazing areas, select gravel pits) and the Idaho Transportation Dept maintains rights-of-way along public roads that pass through the INL site. INL CRM staff members have established productive relationships with cultural resource managers and other personnel in these two organizations (BLM and ITD) and often share information for resource identification, assessment, and protection. In FY 2010, INL CRM staff members cooperated with these organizations to complete archaeological surveys and Section 106 consultation for several proposed new snow fences on INL and BLM lands along a stretch of US Hwy 20 between Idaho Falls and MFC to enhance the safety of this roadway for the public and INL employees, alike. 


\section{NATIVE AMERICAN PARTICIPATION}

As a federal agency, DOE-ID recognizes its trust responsibility to the Shoshone-Bannock Tribes and in the spirit of that responsibility has entered into an Agreement in Principle (AIP) with them (DOE-ID 2009). The AIP defines working relationships between the Shoshone-Bannock Tribes and DOE-ID and fosters a mutual understanding and commitment to engender confidence that activities being conducted at the INL protect the health, safety, and environment, including cultural resources of importance to the Tribes. To aid with implementing cultural resource aspects of the AIP, a Cultural Resources Working Group (CRWG) comprised of representatives from the Shoshone-Bannock HeTO, DOE-ID, and the INL CRMO was established in 1993. It was the first of its kind within the DOE complex and its regular CRWG meetings enable issues and opportunities to be addressed in an environment of mutual respect and learning. Tribal input is sought for new and ongoing projects and a standing invitation is extended to comment on, visit, observe, and/or assist in INL CRMO field activities. The holistic view of cultural resources and cooperative spirit encouraged in this group are designed to enhance understanding and appreciation of all types of cultural resources, both within the INL community and the Tribes. For more detail on the relationship between the INL and the Tribes, and detailed working procedures, see Appendix B of the INL CRMP (DOE-ID 20011).

During FY 2010 the CRMO staff organized a tour for tribal members to Aviator's Cave and participated in all scheduled CRWG meetings. HeTO staff were routinely invited into the field to discuss projects, view survey findings, monitor sensitive cultural resources, and to participate in fieldwork (surveys and test excavations). The assistance provided by tribal partners was important in meeting project milestones.

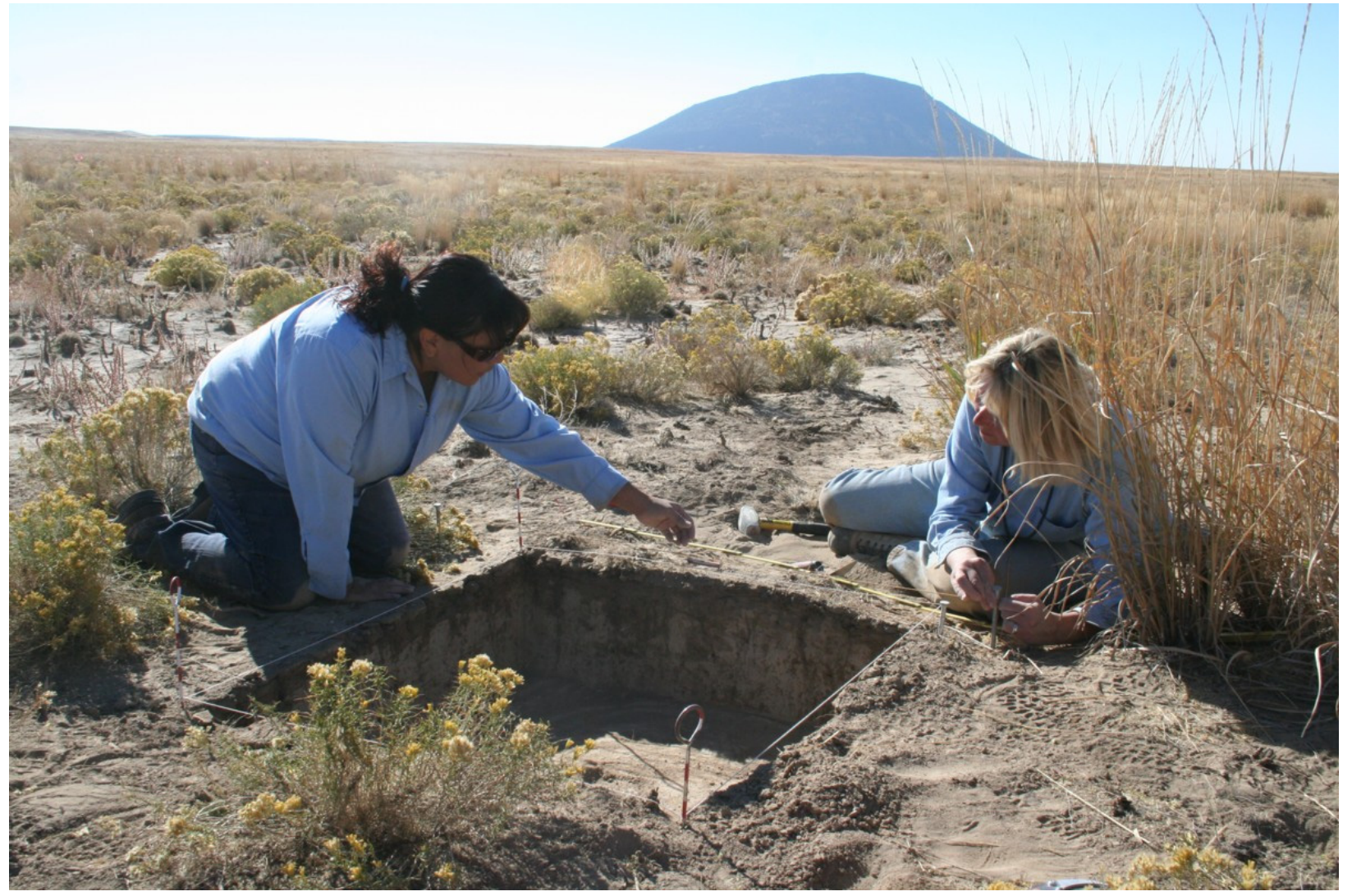

Figure 25. Tribal and INL archaeologists conducting project test excavation. 


\section{NHPA SECTION 106 PROJECT REVIEWS}

The INL is an active facility where thousands of work orders for projects ranging from lawn care to new facility construction are processed each year. Detailed procedures are in place to evaluate the environmental consequences of all activities, large or small. Under company procedures and the INL CRMP, cultural resource reviews are an integral part of the environmental review process and are completed to assess impacts to all cultural resources and to develop recommendations for protection and/or mitigation, when necessary. The goal of the cultural resource review is to determine if the proposed project will affect properties that are eligible for the National Register, if they are Category 1, 2, 3 , or Signature properties based on their relative historic importance, and determine appropriate levels of standard mitigation and/or consultation necessary to establish new mitigation measures. As outlined in the INL CRMP, the process used to make this determination includes archive and record searches and survey.

A review is prompted whenever a project is proposed that meets one or more of the following basic thresholds:

- Ground disturbance outside the boundaries of fenced INL facility areas or more than 50 feet from existing buildings or landscaped areas in unfenced areas

- Ground disturbance within or around the former Power Burst Facility (PBF), now designated as the Critical Infrastructure Test Range Complex (CITRC)

- Activities within known or suspected zones of Native American sensitivity and/or high archaeological resource density

- Demolition, major structural or landscape modification, permanent closure of extant buildings and structures, and/or removal of original equipment, features, or records

- Activities that may affect the Experimental Breeder Reactor I National Historic Landmark building and grounds

FY 2010 reviews for projects affecting historic architectural resources are summarized in Section 9.1. Non-architectural project reviews are presented in Section 9.2.

\subsection{Historic Architectural Reviews}

The INL contains various property types that are elements of, or have features that contribute to, the overall landscape and understanding of the INL's recent World War II and pioneering nuclear history (1942 - 1970). In contrast to the near single focus on mitigating DD\&D work conducted in recent years, in FY 2010 CRMO staff were also involved in conducting architectural reviews for the rehabilitation of existing structures for reuse, installation of new equipment and/or removal of old equipment. The primary focus of FY 2010 project reviews was the removal or demolition of historic properties and consolidation of INL facilities to three campus areas. Due to the nature of the cleanup work and the fact that INL remains an active scientific and technical facility; such activities have impacted, or will impact, historic INL architectural properties (i.e., buildings, structures, equipment, original program and project data).

Thirteen project reviews were conducted in FY 2010 for proposed activities, including one for the removal of the EBR II reactor vessel and superstructure. NHPA Section 106 consultation was initiated with the Idaho SHPO and a Historic American Engineering Record report was drafted as mitigation for the adverse impact of demolition on this historic property. Four additional historic properties were also scheduled for demolition and photographs were completed as required by Programmatic Agreement (PA), following strategies outlined in the INL CRMP. Two project reviews determined the proposed activities 
would not have an adverse impact and the remaining six project reviews involved either exempted properties or exempted activities Table 1).

Table 1. Historic architectural project reviews completed in FY 2010.

\begin{tabular}{|c|c|c|c|}
\hline $\begin{array}{l}\text { Project } \\
\text { Number }\end{array}$ & Project Name & $\begin{array}{l}\text { Property } \\
\text { Category }\end{array}$ & Review Status \\
\hline $10-01$ & $\begin{array}{l}\text { ANL-767 EBR II vessel and } \\
\text { superstructure removal }\end{array}$ & Category 1 & PA-Draft HAER completed \\
\hline $10-02$ & $\begin{array}{l}\text { CF-661 non-original interior } \\
\text { plywood wall removal }\end{array}$ & Category 3 & PA-no adverse impact \\
\hline $10-03$ & $\begin{array}{l}\text { TRA- } 670 \text { replacement of } \\
\text { existing casks }\end{array}$ & Signature & PA - exempt activity \\
\hline $10-04$ & $\begin{array}{l}\text { CF- } 638 \text { air conditioner } \\
\text { installation }\end{array}$ & Category 2 & PA-exempt activity \\
\hline $10-05$ & CF-666 demolition & Category 3 & PA-35mm photos completed and archived \\
\hline $10-06$ & B16-610 demolition & Category 3 & PA-35mm photos completed \\
\hline $10-08$ & B16-606 demolition & Category 3 & PA-35mm photos completed \\
\hline $10-08$ & B16-605 demolition & Category 3 & PA-35mm photos completed \\
\hline $10-09$ & $\begin{array}{l}\text { CF-699 nonstructural interior } \\
\text { wall removal }\end{array}$ & Category 3 & PA-no adverse impact \\
\hline $10-10$ & $\begin{array}{l}\text { PBF-601 and PBF- } 619 \text { septic } \\
\text { tank and seepage pit closure }\end{array}$ & Exempt & PA-exempt properties \\
\hline $10-11$ & $\begin{array}{l}\text { TAN-629 wall penetrations for } \\
\text { safety and fire protection } \\
\text { systems cable }\end{array}$ & Signature & PA-exempt activity \\
\hline $10-12$ & $\begin{array}{l}\text { New INTEC monitoring wells } \\
\text { within the fence }\end{array}$ & Exempt & PA-exempt property \\
\hline $10-13$ & $\begin{array}{l}\text { MFC-752B wall penetrations } \\
\text { for cable }\end{array}$ & Exempt & PA-exempt property \\
\hline
\end{tabular}


Table 2. (continued).

\subsection{Other Cultural Resource Reviews}

During FY 201027 INL projects involving ground disturbance were screened for potential impacts to non-architectural cultural resources (Tables 3 and 4). Resources of concern in these reviews were archaeological sites from the prehistoric and historic periods, historic trails, and less tangible Native American and stakeholder values and concerns. Only one project in FY 2010 was conducted outside the boundaries of the INL site. This project

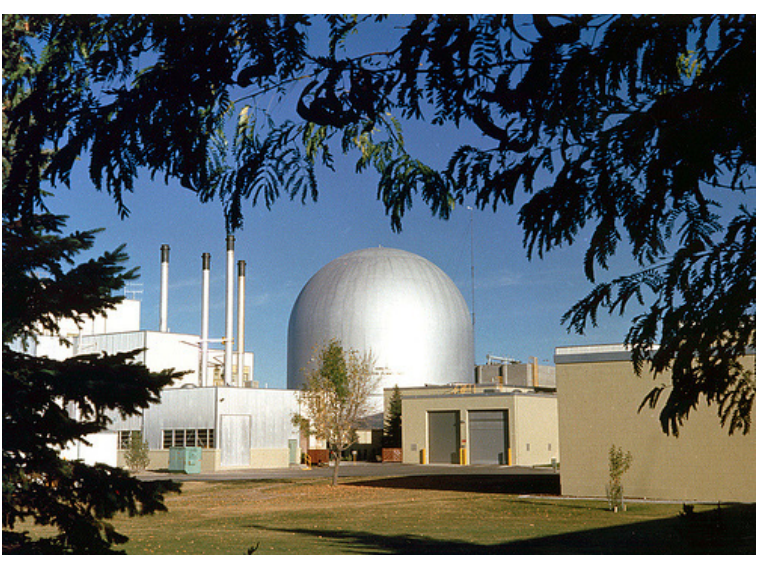

Figure 26. EBR-II Reactor Complex. involved surveys of proposed new snow fences located along U. S. Highway 20 between Idaho Falls and the entrance to the Materials and Fuels Complex. All of the remaining projects and even one segment of the snow fence project were located on INL lands at various locations across the desert site. INL CRM staff members also provided input to NEPA Environmental Assesments for the Remote Handled Low Level Waste Facility, the Multipurpose Haul Road, the Standoff Experiment (SOX) Test Range, and the Radiological Response Test Range.

Table 2. Non-architectural project reviews completed in FY 2010.

\begin{tabular}{|l|l|l|l|l|}
\hline \multicolumn{1}{|c|}{ Project \# } & \multicolumn{1}{|c|}{ Project Name } & \multicolumn{1}{|c|}{$\begin{array}{c}\text { Acres } \\
\text { INL CRMO Activities }\end{array}$} & \multicolumn{1}{c|}{$\begin{array}{c}\text { Cural } \\
\text { Resources } \\
\text { Identified }\end{array}$} \\
\hline BEA-10-01 & INL Wind Towers & $\begin{array}{l}\text { Environmental } \\
\text { Checklist review }\end{array}$ & None & None \\
\hline BEA-10-02: & $\begin{array}{l}\text { UAV Operations for Loop } \\
\text { Tests }\end{array}$ & $\begin{array}{l}\text { Environmental } \\
\text { Checklist review }\end{array}$ & None & None \\
\hline BEA-10-03: & $\begin{array}{l}\text { Snow Fences for Idaho } \\
\text { Transportation Department }\end{array}$ & $\begin{array}{l}\text { Archaeological survey } \\
\text { and reporting }\end{array}$ & $\begin{array}{l}\text { INL: } 54 \text { acres } \\
\text { Off INL: } 97 \\
\text { acres }\end{array}$ & 3 isolates \\
\hline BEA-10-04: & $\begin{array}{l}\text { Wireless Test Bed Activities } \\
\text { (Project M, Cell site 8, INL Pi, } \\
\text { SWIFT, RF } \\
\text { Spectrum, USG power } \\
\text { demonstration) }\end{array}$ & $\begin{array}{l}\text { Environmental } \\
\text { Checklist review }\end{array}$ & None & None \\
\hline
\end{tabular}


Table 2. (continued).

\begin{tabular}{|c|c|c|c|c|}
\hline Project \# & Project Name & INL CRMO Activities & $\begin{array}{c}\text { Acres } \\
\text { Surveyed } \\
\end{array}$ & $\begin{array}{l}\text { Cultural } \\
\text { Resources } \\
\text { Identified } \\
\end{array}$ \\
\hline BEA-10-05: & $\begin{array}{l}\text { Areva Powerline } \\
\text { (NorthWind permit) }\end{array}$ & $\begin{array}{l}\text { Cultural resource } \\
\text { permit oversight }\end{array}$ & 687 & $\begin{array}{l}1 \text { isolate } \\
9 \text { sites, which } \\
\text { include } 1 \text { historic } \\
\text { telephone line } \\
\text { and the historic } \\
\text { Arco Highway }\end{array}$ \\
\hline BEA-10-06: & $\begin{array}{l}\text { NSTR activities (road } \\
\text { maintenance, fiber optic } \\
\text { tests) }\end{array}$ & $\begin{array}{l}\text { Environmental } \\
\text { Checklist review and } \\
\text { monitoring of known } \\
\text { resources }\end{array}$ & None & None \\
\hline BEA-10-07: & $\begin{array}{l}\text { Small NRF Projects } \\
\text { (alternate gravel pit, } \\
\text { CERCLA cleanup, well } \\
\text { expansion) }\end{array}$ & $\begin{array}{l}\text { Archaeological survey } \\
\text { and cultural review }\end{array}$ & 30 acres & $\begin{array}{l}2 \text { isolates } \\
2 \text { sites }\end{array}$ \\
\hline BEA-10-08: & $\begin{array}{l}\text { Small CWI Projects } \\
\text { (INTEC Wells, INTEC and } \\
\text { ATR RWMC water line, } \\
\text { cold } \\
\text { test pit activities, drainage } \\
\text { improvements, well } \\
\text { closures) }\end{array}$ & $\begin{array}{l}\text { Archaeological survey } \\
\text { and Environmental } \\
\text { Checklist review }\end{array}$ & 5 acres & None \\
\hline BEA-10-09: & Grid 47 Fire Breaks & Archaeological survey & 20 acres & 1 isolate \\
\hline BEA-10-10: & $\begin{array}{l}\text { Remote Handled Low } \\
\text { Level Waste Disposal } \\
\text { Project }\end{array}$ & $\begin{array}{l}\text { Archaeological survey } \\
\text { and reporting }\end{array}$ & 200 acres & $\begin{array}{l}2 \text { isolates } \\
2 \text { sites } \\
\text { Historic canals }\end{array}$ \\
\hline BEA-10-11: & T-24/T-25 Haul Road EA & $\begin{array}{l}\text { Archaeological survey } \\
\text { and reporting to } \\
\text { support Environmental } \\
\text { Assessment }\end{array}$ & 341 acres & $\begin{array}{l}7 \text { isolates } \\
3 \text { sites }\end{array}$ \\
\hline BEA-10-12: & $\begin{array}{l}\text { Standoff Experiment (SOX) } \\
\text { Test Range at TAN }\end{array}$ & $\begin{array}{l}\text { Archaeological survey } \\
\text { to support } \\
\text { Environmental } \\
\text { Assessment }\end{array}$ & 379 acres & 20 resources \\
\hline BEA-10-13: & $\begin{array}{l}\text { New INL Information } \\
\text { Signs }\end{array}$ & $\begin{array}{l}\text { Environmental } \\
\text { Checklist review }\end{array}$ & None & None \\
\hline BEA-10-14: & $\begin{array}{l}\text { FEMA Survey on East } \\
\text { Butte }\end{array}$ & $\begin{array}{l}\text { Received report for } \\
\text { CRM files }\end{array}$ & None & None \\
\hline BEA-10-15: & $\begin{array}{l}\text { Ordnance Remediation at } \\
\text { LMFB, Railcar, EFS, } \\
\text { MDA, and NODA }\end{array}$ & $\begin{array}{l}\text { Environmental } \\
\text { Checklist review }\end{array}$ & None & None \\
\hline BEA-10-16: & $\begin{array}{l}\text { MFC Wastewater System } \\
\text { Upgrade }\end{array}$ & $\begin{array}{l}\text { Archaeological } \\
\text { survey, monitoring of } \\
\text { known resources, and } \\
\text { reporting }\end{array}$ & 80 acres & 1 isolate \\
\hline
\end{tabular}


Table 2. (continued).

\begin{tabular}{|c|c|c|c|c|}
\hline Project \# & Project Name & INL CRMO Activities & $\begin{array}{c}\text { Acres } \\
\text { Surveyed } \\
\end{array}$ & $\begin{array}{c}\text { Cultural } \\
\text { Resources } \\
\text { Identified } \\
\end{array}$ \\
\hline BEA-10-17: & $\begin{array}{l}\text { Radiological Response Test } \\
\text { Range }\end{array}$ & $\begin{array}{l}\text { Archaeological survey } \\
\text { to support } \\
\text { Environmental } \\
\text { Assessment }\end{array}$ & 188 acres & 17 resources \\
\hline BEA-10-18: & MFC Road Upgrades & $\begin{array}{l}\text { Environmental } \\
\text { Checklist review }\end{array}$ & None & None \\
\hline BEA-10-19: & $\begin{array}{l}\text { Grid Enhancement EA } \\
\text { (preliminary evaluation) }\end{array}$ & $\begin{array}{l}\text { Feedback on } \\
\text { archaeological } \\
\text { sensitivity for future } \\
\text { planning }\end{array}$ & None & None \\
\hline BEA-10-20: & Jefferson Fire & $\begin{array}{l}\text { Archaeological survey } \\
\text { of firebreaks in highly } \\
\text { sensitive areas; } \\
\text { ongoing evaluation in } \\
2011\end{array}$ & 5 acres & None \\
\hline BEA-10-21: & $\begin{array}{l}\text { Stoller/UI Fire Erosion } \\
\text { Monitors }\end{array}$ & $\begin{array}{l}\text { Environmental } \\
\text { Checklist review }\end{array}$ & None & None \\
\hline BEA-10-22: & $\begin{array}{l}\text { MFC Firing Range Sign } \\
\text { Replacements }\end{array}$ & $\begin{array}{l}\text { Environmental } \\
\text { Checklist review }\end{array}$ & None & None \\
\hline BEA-10-23: & $\begin{array}{l}\text { Power Pole Replacements } \\
\text { after Jefferson Fire }\end{array}$ & $\begin{array}{l}\text { Environmental } \\
\text { Checklist review }\end{array}$ & None & None \\
\hline BEA-10-24: & $\begin{array}{l}\text { Stoller Pygmy Rabbit } \\
\text { Studies }\end{array}$ & $\begin{array}{l}\text { Archaeological } \\
\text { monitoring during soil } \\
\text { testing }\end{array}$ & 10 acres & 11 \\
\hline BEA-10-25: & Stoller Bat Monitors & $\begin{array}{l}\text { Environmental } \\
\text { Checklist review }\end{array}$ & None & None \\
\hline BEA-10-26: & Middle Butte Fire & $\begin{array}{l}\text { Ongoing evaluation in } \\
2011\end{array}$ & & \\
\hline BEA-10-27: & $\begin{array}{l}\text { Adams Blvd Gravel Pit } \\
\text { Bison Bone }\end{array}$ & $\begin{array}{l}\text { Inadvertent discovery } \\
\text { investigation }\end{array}$ & None & None \\
\hline
\end{tabular}

Archive reviews were completed for the 27 projects listed in Table 2. In nine of the 27 FY 2010 project reviews, archival information indicated that no archaeological resources would be affected by the activities proposed. In one case, feedback was provided on archaeological sensitivity for pre-project planning and initial facility siting analysis. In the remaining 17 cases, field investigations ranging from .5 - 379 acres in size were conducted on lands that had never been archaeologically surveyed or in areas where previous surveys were completed more than a decade ago. Approximately 1,432 acres were intensively examined during these project surveys and 59 new archaeological sites and several historic canals were identified and recommended for avoidance or other protective measures.

One of the larger surveys completed in FY 2010 involved examination of a new route for a proposed multipurpose haul road to transport materials between the Materials and Fuels Complex (MFC) and other INL site facilities. Approximately 341 acres were surveyed in FY 2010 to support the new alignment located south of an existing powerline and 24 previously recorded and newly recorded cultural resources were identified within the area of potential effects for construction. In FY 2011, a series of test 
excavations will be completed at select archaeological resources and other protective measures will be implemented to prevent any adverse impacts to the identified resources.

Archaeological surveys to support geophysical investigation and engineering studies of two plots under consideration for construction of a new Remote Handled Low Level Waste Facility were completed in FY 2010 within and area totaling approximately 200 acres. These surveys resulted in the identification of one historic homestead (ca. 1878-1930), one historic debris scatter (ca. 1850-1942), two isolated prehistoric artifacts, and several historic canals and ditches (ca. 1878-1930). Once a construction site is selected, protective measures will be implemented to ensure that significant properties are not adversely affected.

Two other large project surveys were completed for Homeland Security; the Radiological Response Training Range (RRTR) and the Stand-Off Experiment Range (SOX), both located north of Test Area North. During the RRTR survey, 17 new cultural resources/sites were discovered within 188 acres of area surveyed. In working with project managers, it will be possible to avoid all known resources with RRTR project boundaries. During the SOX survey, 20 new cultural resources/sites were discovered within the 379 acres of area surveyed. To avoid impacting a site and in the spirit of stewardship, the SOX project personnel were willing to relocate key elements of their project such as an access road.

In FY 2010, two wildfires swept through INL lands, including the largest such fire in INL history and another that burned near and over Middle Butte Cave. Driven by extremely high winds, the July 13, 2010 Jefferson Fire burned 79,339 acres on INL and 29,516 acres off INL. The August 27, 2010 Middle Butte Fire burned 13,008 acres on the INL and 1131 acres off the INL. Fire suppression activities create potential for impacts to sensitive cultural resources. Impact assessments conducted in FY 2010, included those in areas of high sensitivity, including one with known human remains, and select known archaeological sites that may have been impacted. This activity is ongoing in FY 2011.

The remaining archaeological field investigations completed in FY 2010 involved examination of areas less than 100 acres in size to support a variety of projects including a new wastewater treatment plant at MFC, gravel pit expansion, railroad upgrades, snow fences, sign replacements, and research and development activities. In all cases, project activities were designed to avoid impacts to sensitive archaeological resources. 
The results of project-specific INL CRM surveys are documented in a number of ways as outlined in the INL "Cultural Resource Management Plan."

Recommendations tailored to specific projects and any archaeological resources that may require consideration are delivered in official e-mail notes that become part of the project's National Environmental Policy Act-driven Environmental Checklist and permanent record. For larger projects, external technical reports are often prepared to synthesize archaeological information and recommendations, including three FY 2010 reports, " Cultural

Resource Investigations for the MFC Wastewater System Upgrade at the INL" (INL/EXT-10-18950, May 2010); "Cultural Resource Investigations for the Remote Handled Low Level Waste Facility at the INL" (INL/EXT-10-19116, June 2010); and "Cultural Resource Investigations for a Multipurpose Haul Road on the INL" (INL/EXT-10-19370, July 2010). Technical assessments are also incorporated into Environmental Assessments and Environmental Impact Statements prepared to support the National Environmental Policy Act.

Shoshone-Bannock Tribal representatives received summary reporting of all archive searches completed during the fiscal year, visited some of the project areas, and provided valuable assistance in Section 110 surveys (see Section 6.0) and project and site monitoring. No special tribal concerns were voiced for any of the FY 2010 INL CRMO archive searches or project-specific field surveys, recommendations, or monitoring. Project plans were modified in all cases to avoid all of the archaeological resources identified. Cultural resource clearance recommendations issued for these projects also included a reminder of the requirements to stop work if any cultural materials were unexpectedly encountered. No test excavations were completed at resources identified during project surveys in FY 2010, however plans were initiated to start FY 2011 test excavations at resources that may be impacted during construction of the Multipurpose Haul Road. Although no cultural materials were unexpectedly encountered during FY 2010 project activities, an observant heavy equipment operator did spot an ancient bone, probably bison, during excavations approximately $10 \mathrm{ft}$ below surface in an INL gravel pit. No artifacts or additional bones were observed at this location. 


\section{PROGRAMMATIC AND PROJECT MONITORING}

A detailed description of the INL CRMO monitoring program is located in Appendix L of the INL CRMP (DOE-ID 2011) and a more detailed account of FY 2010 activities can be found in the INL Cultural Resource Monitoring Report (INL/EXT-10-20270). Monitoring enables the INL CRMO to document if the integrity of known resources is being compromised by natural processes, unauthorized activities, or inadvertently by INL projects. By identifying impacts and impact levels and types to cultural resources in this manner, actions to avert further deterioration can be initiated and federal stewardship responsibilities fulfilled.

There are two types of monitoring, programmatic and project specific. In FY 2010, thirty monitoring forms were completed throughout the year to document forty-one site visits, to assess impacts from fire suppression activities on highly sensitive resources, project compliance with cultural resource recommendations, to confirm the locations of specific cultural resources in relation to project activities, and to watch for cultural materials during ground disturbing activities in sensitive areas. Representatives from INL projects, DOE-ID, and the Shoshone-Bannock Tribe's HeTO participated in several of the trips (Figure 1). Throughout the year, some Type 2 impacts, including animal burrowing and erosion, were noted and trespassers apprehended by INL security forces near sensitive locations were cited. However, the National Register integrity of all of the resources that were monitored remains intact. No adverse impacts were documented.

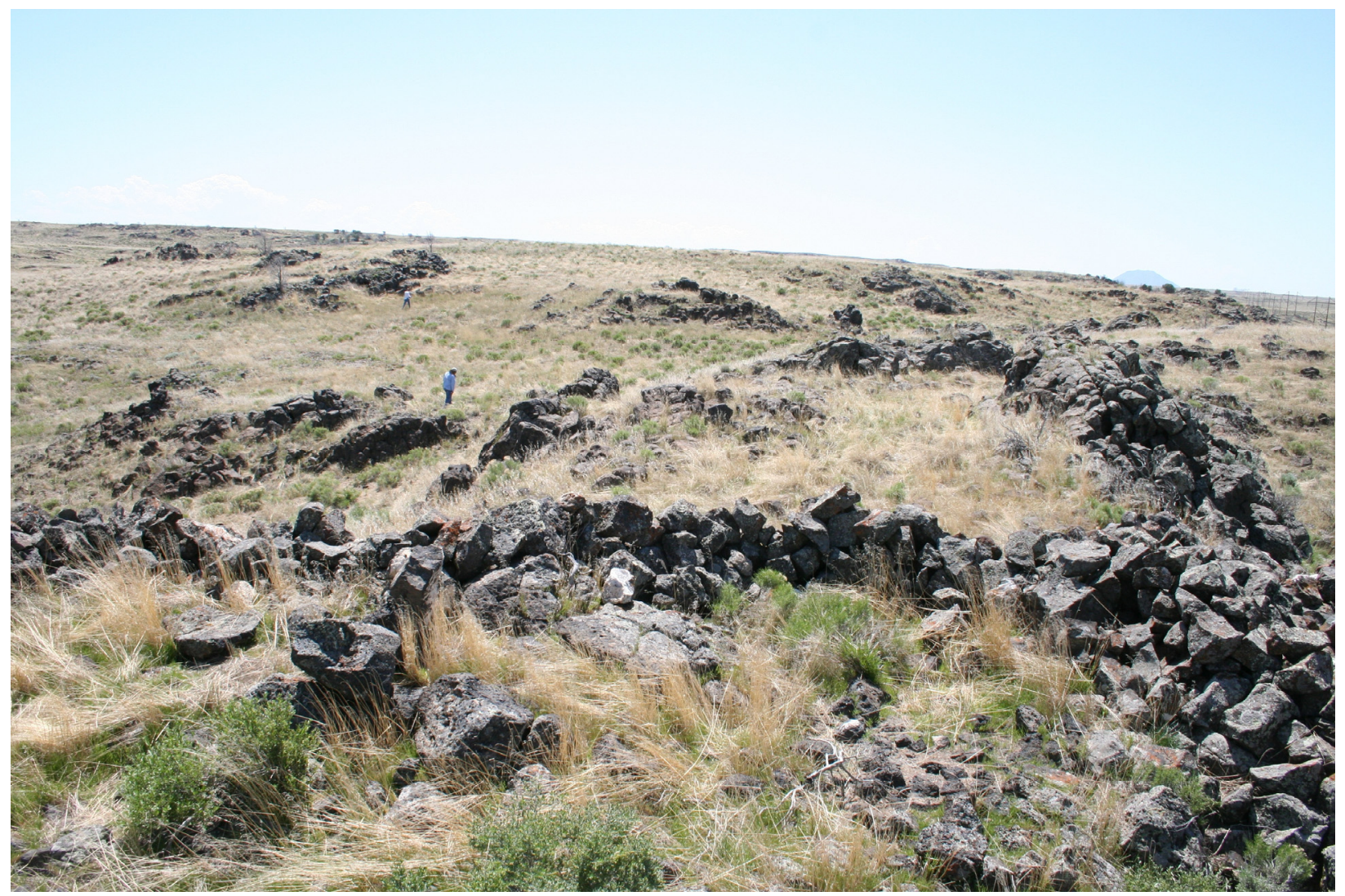

Figure 28. INL CRM and HeTO tribal representatives at 10-JF-88 (Hellofasite). 
Specific cultural resources are chosen for monitoring based on INL CRM Office priorities as well as feedback from DOE-ID, the Shoshone-Bannock Tribes Heritage Tribal Office (HeTO), and INL stakeholders. The INL CRM archives, which include documentation of nearly 3,000 archaeological resources and nearly 300 historic buildings and other structures, are also consulted for appropriate candidates for yearly monitoring. Both DOE-ID and the Shoshone-Bannock Tribes are often directly involved in fieldwork during the monitoring activities and INL project managers and other stakeholders, such as the Idaho State Historic Preservation Office (SHPO), also participate occasionally. Certain resources, like Middle Butte, Prickly, and Aviators Caves, sensitive localities inside the Critical Infrastructure Test Range Complex (CITRC), and the Experimental Breeder Reactor-I (EBR-I) National Historic Landmark, are monitored annually. Others, such as historic homesteads and some prehistoric archaeological sites may also be visited routinely because of their location in highly visible and/or accessible areas where trespassing has been documented in the past. Each year INL CRM staff also conducts surveillance of resources in a wide variety of settings to address ongoing research interests and the overall focus of INL construction and project activities.

\subsection{Project Monitoring}

Several types of project-specific cultural resource monitoring were conducted in FY 2010. Twentysix archaeological sites previously recorded in the vicinity of INL projects were monitored to assess their current condition and develop recommendations for avoiding future impact. In a second type of project monitoring in FY 2010, INL projects were audited for compliance with cultural resource recommendations made during the INL environmental review process. Finally, in a third type of project monitoring, ground disturbance associated with INL project activities in archaeologically sensitive areas was directly observed by INL CRM staff. In total, five projects were monitored as identified and described below.

\subsubsection{National Security Test Range}

The Environmental Assessment (EA) completed for the National Security Test Range (DOE-ID 2007) included minimal requirements for protection of cultural resources such as:

- Limit ATV travel and signage [around the safety fan perimeter] to areas outside the boundaries of any identified cultural resources to prevent disturbance;

- Support yearly visits of known archaeological resources in the project area by an INL archaeologist and take additional protective measures as necessary; and

- Coordinate work with an INL archaeologist to avoid scraping and leveling activities inside the boundaries of identified archaeological sites.

In response to this guidance, eight sites were monitored in FY 2010 to assess impacts from project activities at the National Security Test Range (10-JF-85, 10-JF-84, 10-JF-83, 10-JF-80, 10-JF-78, 10-JF77, 10-BM-123, BEA-06-20-07). Project compliance was confirmed and no new impacts or evidence of unauthorized visitation were observed at these eight sites.

\subsubsection{Multipurpose Haul Road}

Fourteen previously recorded prehistoric lithic scatters located in the vicinity of the T-25 access road were re-identified, reassessed, and monitored in advance of a proposed project to construct a multipurpose haul road between MFC and CITRC (10-BT-1246, 10-BT-1059, 10-BT-1062, 10-BT-1063, 10-BM-109, 10-BT-1049, 10-BT-1053, 10-BT-1247, 10-BT-1052, LMIT-1997-16-22, 10-BM-118, 10-BM-115, 10BM-112, 10-BM-110) (Pace et al. 2010). The INL CRM staff continues to work closely with DOE-ID 
and construction project personnel to clearly mark the sensitive areas and reinforce the need to avoid scraping and leveling activities within them in compliance with the EA (DOE-ID 2010).

\subsubsection{Naval Reactors Facility}

One site (EGG-91-12-01) was re-identified and monitored to facilitate avoidance during exploration for a new gravel source. Artifacts from the site, located along an abandoned, dry channel of the Big Lost River, continue to erode from the bank suggesting subsurface deposits. INL CRM staff will continue to monitor this site as gravel exploration and other development near NRF accelerates over the next few years.

\subsubsection{MFC Wastewater System Upgrade}

INL CRM staff and a representative from the Tribal HeTO re-identified one prehistoric lithic scatter (10-BM-247) in advance of a proposed project to upgrade the MFC wastewater system. It was noted that a road had been bladed through the site's northern portion; however, most of the artifacts to the south remain undisturbed. One Elko-eared point base identified in the original survey documentation was not found. It was determined that impacts to the site are not significant, undisturbed cultural deposits remain intact (Pace et al. 2010). If and when the proposed project is undertaken, INL CRM staff will conduct monitoring as the work is completed.

\subsubsection{Power Burst Facility-Critical Infrastructure Test Range Complex}

Company environmental procedures require project managers to contact the INL CRM Office in advance of ground disturbance within the fenced boundary of CITRC. This is due to the occurrence of human remains in original as well as secondary (i.e. disturbed) contexts at two separate locations within the facility (10-BT-1991, 10-BT-2046). Accelerated cleanup across the INL and new activities to support National Security have resulted in an increase in the number of projects at this facility. In FY 2010, routine monitoring of ground disturbing activities for the Wireless Test Bed project (new temporary towers, mowing under powerlines, electrical trenching) revealed no artifacts or human remains. INL CRM staff will continue routine monitoring of excavation projects in this sensitive area and sensitivity training for workers as per the requirements of LWP-8000, MCP-3480 and the wishes of the ShoshoneBannock Tribes. 


\section{FISCAL YEAR 2011 ACTIVITIES}

At the time of this writing, FY 2011 work is well underway and many tasks have already been completed. Listed below are specific FY 2011 tasks organized in accordance with the broad goals outlined in Section 5.

\section{Goal 1: Identify and Manage INL Cultural Resources}

Task 1. Conduct two interviews of former INL employees.

Task 2. Conduct site testing associated with the multi-year human riverine/lacustrine adaptations project.

Task 3. Enter FY 2010 site forms into INL cultural resources database.

Task 4. Revisit and re-record, if appropriate, select Euro-American sites.

Task 5. Update INL geographical information system files and server and continue quality control activities including resolution with Archaeology database.

Task 6. Perform direct project-related cultural resource reviews (i.e., survey, reports)

\section{Goal 2: Evaluate National Register Eligibility of INL Properties}

Task 1. Continue ongoing refinement of INL historic contexts and research designs based on new information and changes in research tools and approaches.

Task 2. Evaluate archaeological sites tested for the human riverine/lacustrine adaptations project using NRHP criteria.

\section{Goal 3: Monitor the Condition of INL Cultural Resources}

Task 1. Visit, assess condition, and complete monitoring forms for Middle Butte, Aviator's, and Prickly Caves, the WERF burial (10-BT-2046), EBR-I and CFA World War II buildings (CF606, CF-607, CF-613, and CF-632) and implement protective actions as necessary. Maintain monitoring files and database.

Task 2. Identify project areas to monitor for potential impacts to INL cultural resources.

Task 3. Monitor ground disturbing activities at CITRC to ensure any additional finds of human remains are handled appropriately.

\section{Goal 4: $\quad$ Protect INL Cultural Resources}

Task 1. Prepare and move INL archival data (i.e., documents, film, photographic negatives, architectural drawings, etc.) gathered to date.

Task 2. Hire and/or train a person to take over the duties of INL archivist with the goal of obtaining certification.

Task 3. Conduct annual fieldworker cultural resource awareness training and seek additional opportunities to remind INL workers of responsibilities for protecting INL cultural resources.

\section{Goal 5: INL Artifact Curation}

Task 1. Prepare artifacts in temporary storage at the INL CRMO for formal accessioning into IMNH. Transport artifacts to IMNH repository.

Task 2. Organize and participate in a visit to the Idaho Museum of Natural History to assess condition and security of INL artifacts. 
Task 3. Determine curation-related activities to be performed by the Idaho Museum of Natural History.

Task 4. Input legacy site forms into the Archaeology database and continue ongoing quality control, including coordination with GIS coverage.

\section{Goal 6: Stakeholder Involvement/Public Outreach}

Task 1. Participate in at least two educational events or tours.

Task 2. Coordinate and conduct a stakeholder meeting/public tour of archaeological sites for Idaho Archaeology and Historic Preservation Month.

Task 3. Track the number of tours and visitors on each tour and tour evaluations.

Task 4. Publish peer-reviewed articles.

\section{Goal 7: Interact with Native Americans}

Task 1. As requested by DOE-ID, assist DOE-ID counterpart in preparation of the annual presentation of INL cultural resource management activities to the Tribal Business Council and attend presentation to answer questions.

Task 2. Facilitate and participate in monthly Cultural Resource Working Group meetings.

Task 3. Facilitate and encourage HeTO participation.

\section{Goal 8: Conduct Work Safely}

Task 1. Conform to ISMS requirements.

Task 2. Inspect equipment regularly.

Task 3. Comply with Archaeology Laboratory Instruction.

\section{Goal 9: Maintain Professional Qualifications and Relationships}

Task 1. Participate in training toward professional archivist certification.

Task 2. Meet with the Idaho SHPO to present report of activities and to discuss upcoming activities.

\section{Goal 10: Activities Reports/Plans}

Task 1. Complete a report of annual activities

Task 2. Complete annual Department of Interior (DOI) questionnaire (Contract Data Requirements List [CDRL] F.45).

Task 3. Complete annual monitoring report (CDRL F. 46). 


\section{REFERENCES}

Anderson, J. E., K. T. Ruppel, J. M. Glennon, K. E. Holte, and R. C. Rope, 1996, "Plant Communities, Ethnoecology, and Flora of the Idaho National Engineering Laboratory," Environmental Science and Research Foundation Report Series, Number 005, Idaho Falls, Idaho.

ARPA, 1979, “Archaeological Resources Protection Act, 1979,” as amended, PL 96-95; 16 USC 470aa, et seq.

Braun, Julie, 2006a, Change as an Historic Feature in the Preservation of Places Related to Science and Technology, MA thesis, Department of Historic Preservation, Goucher University, Baltimore, MD, 2006.

Bright, Robert C. and O. K. Davis, 1982 Quaternary Paleoecology of the Idaho National Engineering Laboratory, Snake River Plain, Idaho. American Midland Naturalist 108(1): 21-23.

Butler, B. Robert, 1968, "An Introduction to Archaeological Investigations in the Pioneer Basin Locality of Eastern Idaho," Tebiwa 11(1), pp. 1-30.

Butler, B. Robert, 1970, “A Report on the 1967-69 Archaeological Survey of the National Reactor Testing Station, Idaho,” Tebiwa 13 (1), pp. 58-75.

Craig, T.H. and C. H. Trost 1976, "The Nesting Birds of the Idaho National Engineering Laboratory Site," Summaries of the Idaho National Engineering Laboratory Ecological Information Meeting, edited by O. Doyle Markham, Idaho Operations Office, U.S. Energy Research and Development Administration, Idaho Falls, Idaho.

Davis, Owen K. and Robert C. Bright, 1983, "Late Pleistocene Vegetation History of the Idaho National Engineering Laboratory," Idaho National Engineering Laboratory Radioecology and Ecology Programs 1983 Progress Report, edited by O.D. Markham, pp.162-171. U.S. Department of Energy. Idaho Operations Office, Idaho Falls, Idaho.

Department of Energy, Idaho Operations Office, 2002, "Final Environmental Assessment for Geomorphic Investigations of the Big Lost River at Site BLR-8 on the INEEL", DOE/EA-1448, September 2002.

Department of Energy, Idaho Operations Office, 2009a, Idaho National Laboratory Cultural Resource Management Plan, DOE/ID-10997, Revision 3, Idaho Falls, ID.

Department of Energy, Idaho Operations Office, 2007, Agreement in Principle with the ShoshoneBannock Tribes, December 2007.

Gerard, H. C., 1982, Wild Horse Jack, privately published, copyright Harry Clay Gerard.

Gianniny, Gary L., Glenn D. Thackray, Darrell S. Kaufman, Steven L. Forman, Michael J. Sherbondy, and Delda Findeisen, 2002, "Late Quaternary Highlands in the Mud Lake and Big Lost Trough Subbasins of Lake Terreton, Idaho," Geology, Hydrogeology, and Environmental Remediation: Idaho National Engineering and Environmental Laboratory, Eastern Snake River Plain, Idaho, Special Paper 353, pp. 77-90.

Marler, Clayton F., 2004, A Paleoindian Context for the Idaho National Engineering and Environmental Laboratory, MA thesis, Department of Anthropology, Idaho State University, Pocatello, Idaho.

Nace, R. L., M. Deutsch, and P. T. Voegli, 1972, "Physical Environment of the National Reactor Testing Station, Idaho: A Summary," U.S. Geological Survey Professional Paper, 725-A, Washington, D.C.

NEPA, 1969, "National Environmental Policy Act of 1969," as amended, PL 91-190; 42 USC 4321 and $4331-4335$. 
NHPA, 1966, "National Historic Preservation Act of 1966," as amended, PL 89-665; 16 USC 470, et seq.

Ostenaa, Dean A., Daniel R. Levish, Ralph E. Klinger, and Daniel R. H. O’Connell, 1999, "Phase 2 Paleohydrologic and Geomorphic Studies for the Assessment of Flood Risk for the Idaho National Engineering and Environmental Laboratory, Idaho," Geophysics, Paleohydrology, and Seismotectonics Group, Technical Service Center, Bureau of Reclamation, Denver, Colorado.

Pace, B. R., D. Lowrey, H. K. Gilbert, J. B. Williams, J. Brizzee, Cultural Resource Investigation for the MFC Wastewater System Upgrade at the INL, INL/EXT-10-18950, May 2010.

Pace, B. R., H. K. Gilbert, J. B. Williams, C. Marler, D. Lowrey, and C. Brizzee, Cultural Resource Investigations for the Remote Handled Low Level Waste Facility at the INL, INL/EXT-10-19116, June 2010.

Pace, B. R., C. Brizzee, H. K. Gilbert, C. Marler, J. B. Williams, and D. Lowrey, Cultural Resource Investigations for a Multipurpose Haul Road on the INL, INL/EXT-10-19370, July 2010.

Plager, S. R., T. L. Johnson, A. Williams, and R. N. Holmer, 2004, "GIS Cultural Resource Predictive Model for the INL," Draft report, September 2004.

Ringe, Brenda. L., 1995, Locational Analysis and Preliminary Predictive Model for Prehistoric Cultural Resources on the Idaho National Engineering Laboratory, MA thesis, Idaho State University, Department of Anthropology, Pocatello, Idaho.

Sehman, R. and A.D. Linder, 1976, "A study of the Amphibian and Reptilian Fauna," Summaries the Idaho National Engineering Laboratory Ecological Information Meeting, edited by O. Doyle Markham, Idaho Operations Office, U.S. Energy Research and Development Administration, Idaho Falls, Idaho. 